\title{
Analysis of the Most Severe Flood Events in Turkey (1960-2014): Which Triggering Mechanisms and Aggravating Pathways Can Be Identified?
}

\author{
Gamze Koç*(D), Theresia Petrow and Annegret H. Thieken \\ Institute of Environmental Science and Geography, University of Potsdam, Karl-Liebknecht-Straße 24-25, \\ 14476 Potsdam, Germany; thpetrow@uni-potsdam.de (T.P.); annegret.thieken@uni-potsdam.de (A.H.T.) \\ * Correspondence: gamze.koc@uni-potsdam.de; Tel.: +49-331-977-2984
}

Received: 21 April 2020; Accepted: 28 May 2020; Published: 30 May 2020

\begin{abstract}
The most severe flood events in Turkey were determined for the period 1960-2014 by considering the number of fatalities, the number of affected people, and the total economic losses as indicators. The potential triggering mechanisms (i.e., atmospheric circulations and precipitation amounts) and aggravating pathways (i.e., topographic features, catchment size, land use types, and soil properties) of these 25 events were analyzed. On this basis, a new approach was developed to identify the main influencing factor per event and to provide additional information for determining the dominant flood occurrence pathways for severe floods. The events were then classified through hierarchical cluster analysis. As a result, six different clusters were found and characterized. Cluster 1 comprised flood events that were mainly influenced by drainage characteristics (e.g., catchment size and shape); Cluster 2 comprised events aggravated predominantly by urbanization; steep topography was identified to be the dominant factor for Cluster 3; extreme rainfall was determined as the main triggering factor for Cluster 4; saturated soil conditions were found to be the dominant factor for Cluster 5; and orographic effects of mountain ranges characterized Cluster 6. This study determined pathway patterns of the severe floods in Turkey with regard to their main causal or aggravating mechanisms. Accordingly, geomorphological properties are of major importance in large catchments in eastern and northeastern Anatolia. In addition, in small catchments, the share of urbanized area seems to be an important factor for the extent of flood impacts. This paper presents an outcome that could be used for future urban planning and flood risk prevention studies to understand the flood mechanisms in different regions of Turkey.
\end{abstract}

Keywords: hierarchical clustering; Hess-Brezowsky Großwetterlagen classification; ERA5; flood hazards; pathway; Turkey

\section{Introduction}

Turkey has been seriously affected by flood events, especially in the last fifty years. Floods have been recorded as the second most destructive natural hazard in Turkey according to the Emergency Events Database (EM-DAT); the Turkish Disaster Database (TABB) reported 1076 flood events causing 795 fatalities and US\$800 million in economic losses in the period 1960-2014 [1]. The severity of floods can be influenced by climatic factors (e.g., weather types and associated rainfall, sudden increase in air temperature, and consecutive sudden snow melt), topographic factors (catchment properties; e.g., shape, size, slope, and elevation), soil properties, land use properties, and human-induced factors (e.g., urbanization, hydraulic engineering practices, and unplanned infrastructure practices) [2]. There are numerous methods for studying a flood triggering conditions and flood classification based on different variables. For example, Nied et al. [3] classified the floods in the Elbe River basin between 
1957 and 2002 based on soil moisture, weather patterns, and flood types to understand the relationship between hydro-meteorological patterns and flood types. Similarly, Turkington et al. [4] classified the floods in two different Alpine catchments, Ubaye (France) and Salzach (Austria), based on temperature, precipitation indicators, and day of the year to identify changes in the distribution of flood types and characteristics of the flood types for future climate scenarios. Prudhomme et al. [5] also classified the flood sensitivity of the catchments in Great Britain for future climate scenarios in a condition of changing precipitation, temperature, and potential evapotranspiration. Schröter et al. [6] evaluated the hydro-meteorological factors (i.e., precipitation, antecedent conditions, initial river flow, and peak flood discharge) using extreme value statistics in order to assess the causal mechanism of the June 2013 flood in Germany. Merz and Blöschl [7] also proposed a framework for flood-causing mechanism identification using diagnostic maps based on flood-process types (i.e., long-rain floods, short-rain floods, flash floods, rain-on-snow floods, and snowmelt floods) at the regional scale. Seasonal patterns of floods are also important for understanding the dominant flood-process types and a good indicator to investigate the flood-causing processes [8]. For example, Beurton and Thieken [8] used the cluster analysis to classify the seasonality of the floods in Germany, which provides important information for understanding the flood-producing mechanisms, such as atmospheric circulation and specific hydrological response.

In Turkey, most flood events were also analyzed as case studies with regard to their meteorological characteristics, including atmospheric conditions and their influence on precipitation patterns or spatial variability of rainfall regimes (e.g., [9-14]). Up to now, there has been no study reflecting upon the main causal factors and aggravating pathways of severe flood events in the aggregate of atmospheric circulation patterns, topography, soil properties, and land use type influences at the national scale. However, for a better flood risk assessment and management, quantification of all processes along the flood risk chain, from the flood-triggering precipitation to the hydrological processes in the catchment, the hydraulic processes in the river system, and the response of the catchment, is required $[15,16]$, since the response of a catchment to a rainfall event differs also depending on topography, drainage characteristics, soil properties, and land use [17]. Merz et al. [18] indicated that statistical approaches are necessary to understand the climatic context of floods and they have to be complemented by the search for the causal mechanisms and dominant processes in the atmosphere, catchment, and river system that have influence on flood characteristics. Therefore, unlike the previous studies, our aim was to develop an approach for evaluating the triggering mechanisms together with the aggravating pathways that led to catastrophic flood events in Turkey between 1960 and 2014.

In all previous studies, hydro-meteorological variables play an important role for the flood classification, while other potentially influencing factors such as catchment properties were neglected. To limit modeling efforts and to better understand the causal mechanisms, a bottom-up approach suggested by Zscheischler et al. [19] was followed. In line with this approach, the events with severe impacts were chosen as a starting point, and drivers and pathways along the whole risk chain were analyzed. From the set of events documented in the TABB and EM-DAT databases, the 25 most severe floods in Turkey were identified, taking into account the number of fatalities and affected individuals as well as economic losses as the main indicators. To conduct a detailed analysis of the triggering mechanisms and aggravating pathways, an important first step is to determine the parameters to be analyzed and accordingly obtain meaningful data; however, there are challenges in obtaining suitable data for large-scale areas. For instance, Hammer et al. [20] indicated that access to large-scale data might be challenging due to their costs or privacy policies. Accessing data for the entirety of Turkey is also challenging due to the costs or privacy policies of different data-providing government institutions. Therefore, our study focused on using accessible datasets for Turkey to answer the main research questions in a way that can be readily transferable to other researchers and countries with similar data policies.

The identification of potentially aggravating mechanisms helps provide an understanding of the floods from occurrence to consequence [21]. Sayers et al. [22] conceptualized the link between 
occurrence and consequence with the Source-Pathway-Receptor-Consequence (SPRC) model. In this flood risk assessment process, the source of the hazard (e.g., rainfall, waves, or storm surges), pathways (e.g., overflow and floodplain inundation), and receptors (e.g., people or properties) must be identified to understand a flood system [22]. Sayers et al. [22] implemented this approach in the United Kingdom and also indicated that it is possible to have multiple sources, pathways, and receptors [21]. Therefore, by identifying the main triggering and aggravating mechanisms, we enable a better understanding of the different pathways and provide information for further flood risk studies by conceptualizing the SPRC model using Turkey as an example (Figure 1).

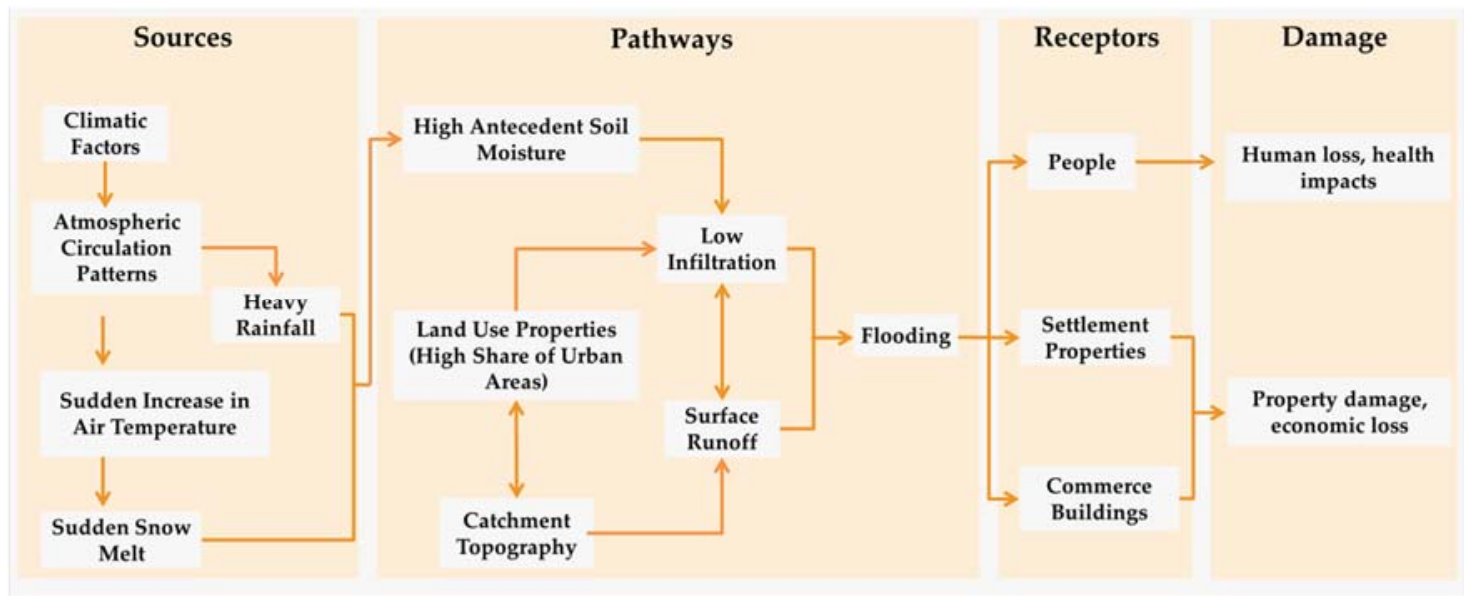

Figure 1. Conceptualized Source-Pathway-Receptor-Consequence (SPRC) model diagram for analyzed flood events (adapted from Sayers et al. [22]).

Floods are complex processes which occur due to a combination of natural and human-induced factors. However, in each flood event, one of these factors plays a relatively more important role than the others. The classification of these factors contributes to a better understanding of flood-generating processes and their pathways and therefore provides an entry point for better management [23]. For the systematic evaluation of these factors and to understand the dominant causal parameters of the events within a comparative assessment, the classification of similar features is a required next step. Therefore, hierarchical cluster analysis was used to group the determined numerical parameters according to their similarity.

With this approach, major aggravating mechanisms and associated pathways for each of the 25 most severe flood events were identified for Turkey during the period 1960-2014.

\section{Study Area, Datasets, and Methods}

\subsection{Study Area}

Turkey is a transcontinental country located mainly on the Anatolian peninsula and acts as a bridge between Europe and Asia. The total surface area of Turkey amounts to $783,562 \mathrm{~km}^{2}$ and the mean elevation is $1132 \mathrm{~m}$ (maximum $5137 \mathrm{~m}$-Mount Ararat). Turkey comprises seven geographic regions (Figure 2) and each region differs with respect to its climatic conditions.

The total annual precipitation ranges from 580 to $1300 \mathrm{~mm}$ in the Aegean and Mediterranean regions, which have a Mediterranean climate with hot, dry summers and mild to cool, wet winters [24]. The Black Sea region has the highest annual precipitation amounts, which reach up to $2500 \mathrm{~mm}$ due to its temperate oceanic climate with warm, wet summers and cold, wet winters [24]. The Marmara region has a transitional climate between a Mediterranean climate and an oceanic climate with warm to hot, moderately dry summers and cool to cold, wet winters with a mean annual precipitation of $662.3 \mathrm{~mm}$ [24]. The Central and Eastern Anatolia regions have a continental climate with hot summers and cold winters and $481.4 \mathrm{~mm}$ mean annual precipitation. Southeastern Anatolia has a transitional 
climate between a Mediterranean climate and a continental climate from west to east. Here, the mean annual precipitation amounts to $532.2 \mathrm{~mm}$ [24].

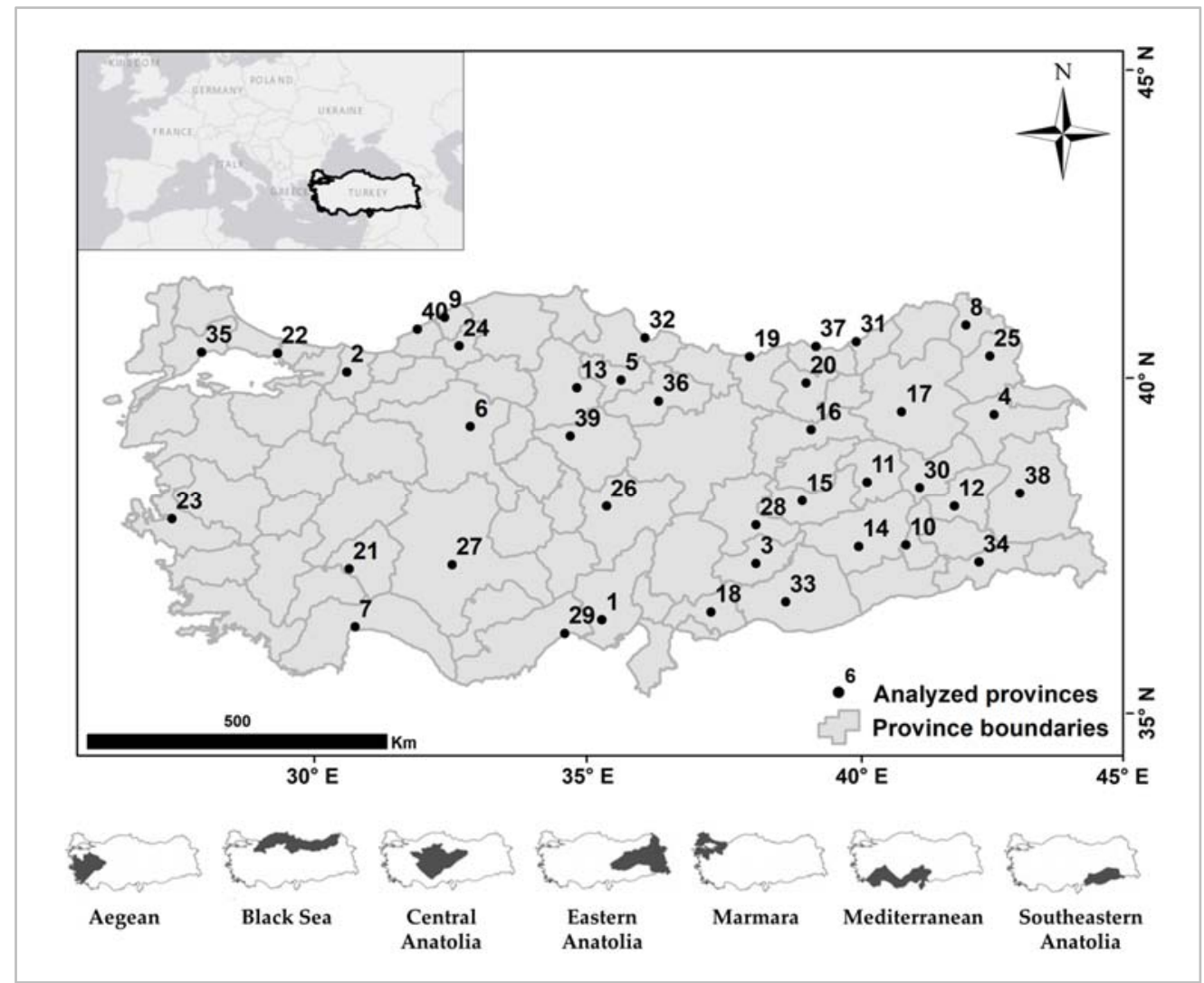

Figure 2. Site location map of the study area, analyzed provinces (numerated, please see the Appendix A, Figure A1 for province names), and geographic regions of Turkey (at the bottom).

The Anatolian peninsula has experienced many floods over the last 50 years, which have caused great societal and economic impacts [1]. The most severe of these events were analyzed in this study with regard to their potential triggering mechanisms (i.e., atmospheric circulations and precipitation amounts) and aggravating pathways (i.e., topography, catchment size, land use types, and soil properties).

\subsection{Datasets}

\subsubsection{The 25 Most Severe Flood Events}

Koç and Thieken [1] compiled a list of the most catastrophic flood hazards between 1960 and 2014 using the information that was available in the Turkey Disaster Database (TABB) and the Emergency Events Database (EM-DAT) (Figure 3). The Global Active Archive of Large Flood Events-Dartmouth Flood Observatory (Dartmouth), related scientific literature, and news archives were additionally used to fill in the gaps in the retrieved event list [1]. These events were ordered by their societal and economic impacts (i.e., the number of fatalities, the amount of economic losses, and the number of affected people) as key indicators for this ranking, which means that the events were selected purely based on their reported impacts. 


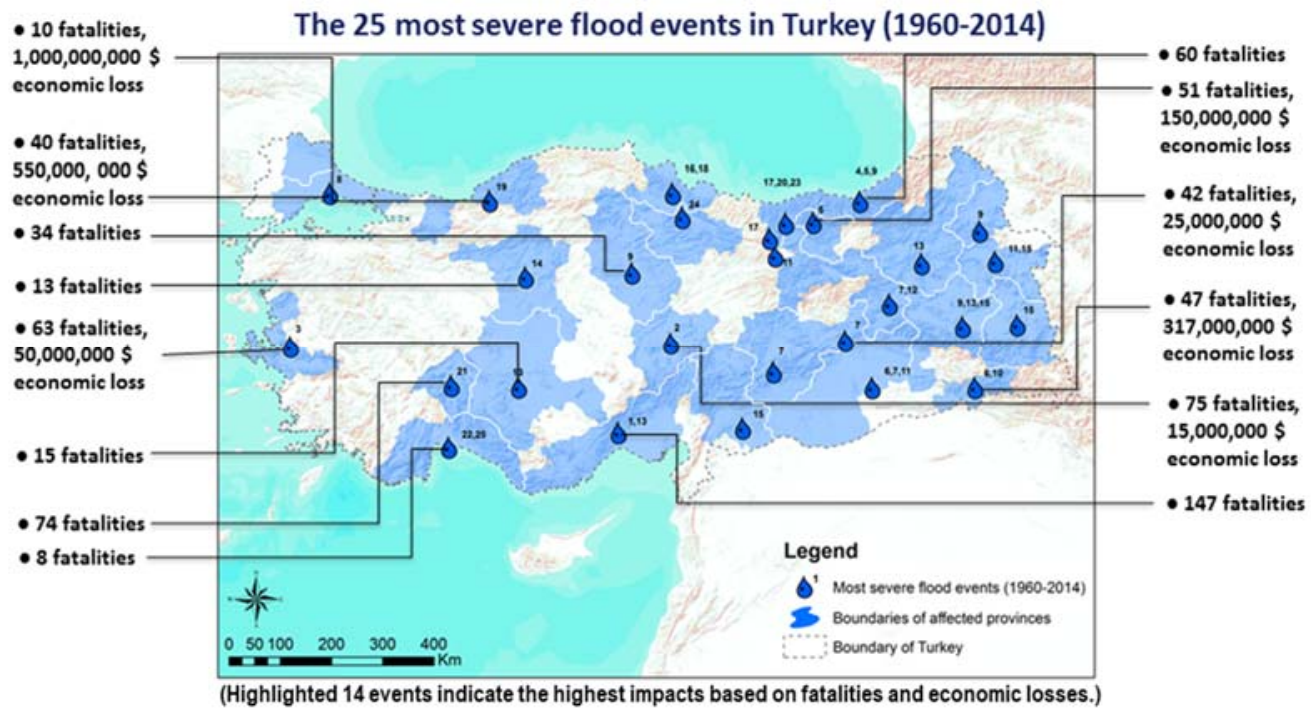

Figure 3. The 25 most severe flood events in Turkey (adapted from Koç and Thieken [1]).

This event dataset was used to analyze the main triggering and aggravating mechanism for each flood event. Since some flood events on the list were large-scale and affected more than one sub-basin, each sub-basin was analyzed as a separate case study resulting in 78 case studies in total. Atmospheric circulation patterns (ACP), precipitation, digital elevation models (DEMs), soil data, and land use were selected for a more detailed analysis and clustering of the main causal mechanisms of the floods on the regional scale. Additional information was acquired from related publications to fill in the gaps in the analyzed dataset.

\subsubsection{Daily Precipitation Data (Turkish State Meteorological Service Dataset, 1960-2014)}

The Turkish State Meteorological Service (TSMS) was founded in 1925 in Ankara to record meteorological data [25] and is the only legal organization that supplies meteorological information in Turkey [26]. The TSMS data are publicly available and it is possible to request all the available data via the Meteorological Data Information Sales and Presentation System (MEVBIS) [27]. The TSMS data can be used for free by Turkish government organizations and Turkish universities with an official request letter. Other users can obtain the data for a certain fee.

The TSMS operates 403 rainfall stations throughout Turkey (Figure 4). Each station has a different starting date of operation and hence each station has a unique record period. TSMS, which started collecting rainfall data manually, introduced Automatic Meteorological Monitoring Stations (OMGI) in 2007 [28]. In this study, we used daily precipitation data (mm/day) from 282 stations for the time period 1960-2014, which had no long interruptions in the recording period (Figure 4). To eliminate the data gaps, we used the ERA5 data to create consistent time series.

TSMS daily precipitation data were related to the relevant Atmospheric Circulation Patterns (ACP) and the Antecedent Soil Moisture (ASM). Precipitation data ( $\mathrm{mm} /$ day) were also included in the cluster analysis (PREC). Sections 2.3.1 and 2.3.3 explain the determination of ACP, ASM, and PREC parameters in more detail. 


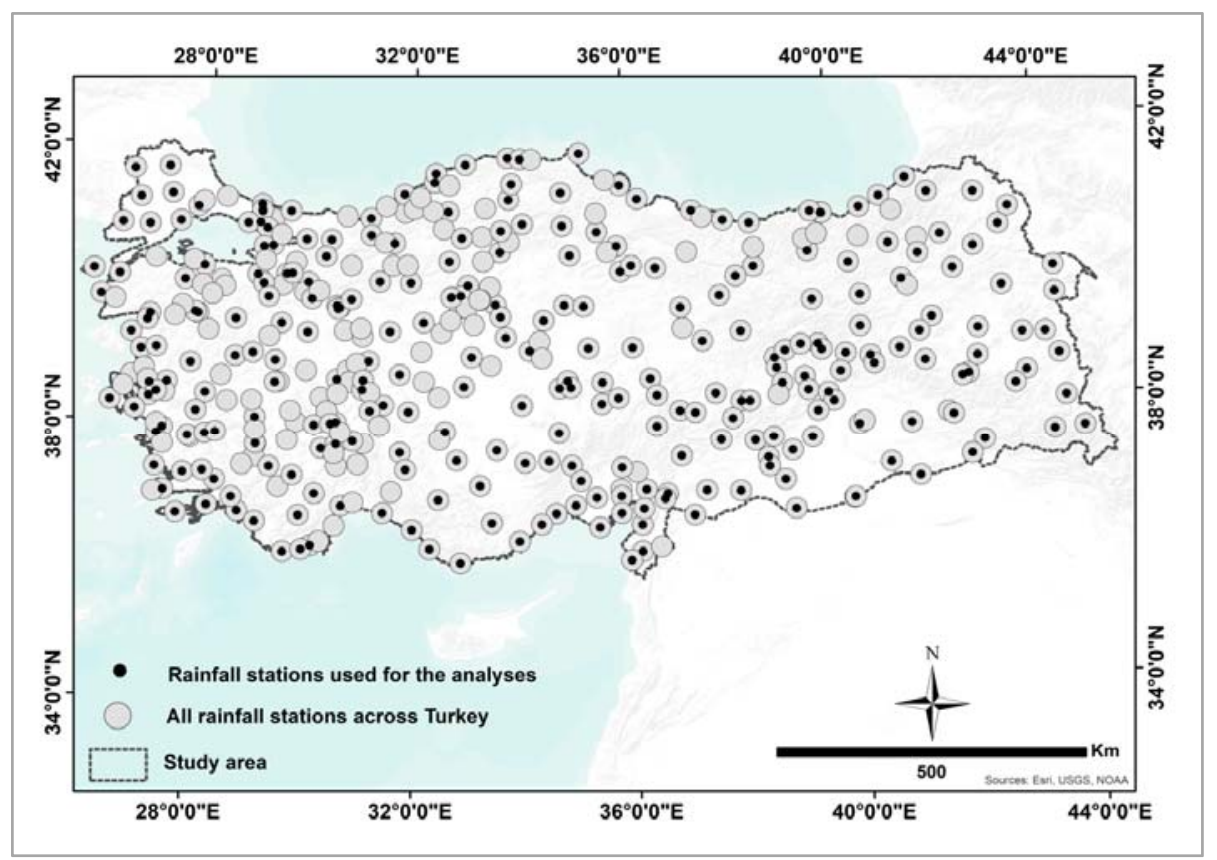

Figure 4. Spatial distribution of rainfall stations in Turkey.

\subsubsection{ERA5—Climate Reanalysis Data}

ERA5 (ECMWF Re-Analysis) is the fifth-generation European Centre for Medium-Range Weather Forecasts (ECMWF) involved in atmospheric reanalysis, which combines modeled data from past observations to generate consistent time series of multiple climate variables from 1979 to the present [29]. ERA5 data are freely available in GRIB format, which have an hourly temporal resolution and are mosaicked in $0.25^{\circ} \times 0.25^{\circ}$ (atmosphere) tiles [29].

For the study, the ERA5 reanalysis (total precipitation parameter) was used to fill the gaps in the TSMS precipitation data to generate a consistent time series for cross-checking the reported event date of the 25 analyzed severe events, the event day precipitation amount (PREC), and related ACPs.

\subsubsection{Hess and Brezowsky Großwetterlagen Catalog (HB-GWL, 1881-2016)}

Atmospheric circulation patterns occur in different local and seasonal settings and vary in their duration. Owing to their potential to absorb moisture, some circulation patterns are more capable of causing flood events than others. To reveal the relevant ACP for Turkey, we analyzed different ACPs.

There are various approaches to classifying ACPs (e.g., [30,31]). Each methodology comprises two main steps: (i) the definition of circulation types; and (ii) the assignment of individual cases to circulation types [30]. ACPs can be defined subjectively and manually using expert knowledge and experience or can be defined using objective numerical methods to generate a set of patterns $[30,32]$. For instance, Türkeş and Tatl1 [12] used a spectral clustering method and defined eight clusters for precipitation regimes during 1929-2007 in Turkey. However, this classification was not usable for this study, since it was based on annual precipitation amounts. Lolis and Türkeş [13] analyzed and classified the precipitation regimes in Turkey during 1979-2011 to disclose the sub-regions that were mostly affected by specific evolution types of ACPs from atmospheric reanalysis data. Baltac1 et al. [9] subjectively determined three main circulation pattern (CP) types in the Marmara region by applying the Lamb Weather Type methodology to a reanalysis of sea-level pressure data for the period 1971-2010. Similarly, Littmann [33] presented twenty weather types in the Mediterranean basin, which also includes western and southwestern Turkey, based on subjective identification between 1992 and 1996. However, these classifications were only used as supportive information in this study and not as the main ACP classification system due to non-overlapping study periods. 
The Hess and Brezowsky Großwetterlagen catalog (HB-GWL) is a subjectively-identified circulation pattern classification system. The Großwetterlagen (GWL) catalog is the only classification system which includes large-scale weather characteristics across Europe and is widely used [34-36]. This catalog was initially designed by Baur et al. [37] and was revised and improved by Hess and Brezowsky [38-40]. HB-GWL was updated by Werner and Gerstengarbe [41] until 2009 and has been continuously updated at the Potsdam Institute for Climate Impact Research (PIK), Germany, since then. There are 30 different CPs defined in the HB-GWL catalog (Table 1) and each CP type was defined based on the spatial distribution of pressure systems and frontal zone locations across Europe [42].

Table 1. Classification, definition, and associated circulation patterns (CPs) of Hess and Brezowsky Großwetterlagen (HB-GWL) catalog (adapted from Hess and Brezowsky [40]).

\begin{tabular}{|c|c|c|c|c|c|}
\hline No. & GWL & $\begin{array}{l}\text { Form of } \\
\text { Circulation }\end{array}$ & $\begin{array}{l}\text { Circulation } \\
\text { Type }\end{array}$ & Original Definition in German & Translated Definition in English \\
\hline 1 & WA & \multirow{4}{*}{ Zonal } & \multirow{4}{*}{ Westerly } & Westlage, antizyklonal & West wind, anti-cyclonic \\
\hline 2 & WZ & & & Westlage, zyklonal & West wind, cyclonic \\
\hline 3 & WS & & & Südliche Westlage & Southern West wind \\
\hline 4 & WW & & & Winkelförmige Westlage & Angular West wind \\
\hline 5 & SWA & \multirow{7}{*}{ Mixed } & Anticyclonic & Südwestlage, antizyklonal & Southwest wind, anti-cyclonic \\
\hline 6 & SWZ & & Cyclonic & Südwestlage, zyklonal & Southwest wind, cyclonic \\
\hline 7 & NWA & & Anticyclonic & Nordwestlage, antizyklonal & Northwest wind, anti-cyclonic \\
\hline 8 & NWZ & & Cyclonic & Nordwestlage, zyklonal & Northwest wind, cyclonic \\
\hline 9 & $\mathrm{HM}$ & & Anticyclonic & Hoch Mitteleuropa & $\begin{array}{l}\text { High pressure system, } \\
\text { Central Europe }\end{array}$ \\
\hline 10 & $\mathrm{BM}$ & & Anticyclonic & $\begin{array}{c}\text { Hochdruckbrücke (Rücken) } \\
\text { Mitteleuropa }\end{array}$ & $\begin{array}{l}\text { High pressure bridge over } \\
\text { Central Europe }\end{array}$ \\
\hline 11 & $\mathrm{TM}$ & & Cyclonic & Tief Mitteleuropa & $\begin{array}{l}\text { Low pressure system, } \\
\text { Central Europe }\end{array}$ \\
\hline 12 & NA & \multirow{19}{*}{ Meridional } & \multirow{6}{*}{ Northerly } & Nordlage, antizyklonal & North wind, anti-cyclonic \\
\hline 13 & $\mathrm{NZ}$ & & & Nordlage, zyklonal & North wind, cyclonic \\
\hline 14 & HNA & & & $\begin{array}{l}\text { Hoch Nordmeer-Island, } \\
\text { antizyklonal }\end{array}$ & $\begin{array}{l}\text { High pressure Iceland-Norwegian } \\
\text { Sea, anti-cyclonic }\end{array}$ \\
\hline 15 & $\mathrm{HNZ}$ & & & Hoch Nordmeer-Island, zyklonal & $\begin{array}{l}\text { High pressure Iceland-Norwegian } \\
\text { Sea, cyclonic }\end{array}$ \\
\hline 16 & HB & & & Hoch Britische Inseln & High pressure, British Isles \\
\hline 17 & TRM & & & Trog Mitteleuropa & Trough Middle Europe \\
\hline 18 & NEA & & Anticyclonic & Nordostlage, antizyklonal & Northeast wind, anti-cyclonic \\
\hline 19 & NEZ & & Cyclonic & Nordostlage, zyklonal & Northeast wind, cyclonic \\
\hline 20 & HFA & & \multirow{4}{*}{ Easterly } & $\begin{array}{l}\text { Hoch Fennoskandien, } \\
\text { antizyklonal }\end{array}$ & $\begin{array}{c}\text { High pressure } \\
\text { Fennoscandia, anti-cyclonic }\end{array}$ \\
\hline 21 & HFZ & & & Hoch Fennoskandien, zyklonal & $\begin{array}{l}\text { High pressure } \\
\text { Fennoscandia, cyclonic }\end{array}$ \\
\hline 22 & HNFA & & & $\begin{array}{l}\text { Hoch Nordmeer-Fennoskandien, } \\
\text { antizyklonal }\end{array}$ & $\begin{array}{l}\text { High pressure Norwegian } \\
\text { Sea-Fennoscandia, anti-cyclonic }\end{array}$ \\
\hline 23 & HNFZ & & & $\begin{array}{l}\text { Hoch Nordmeer-Fennoskandien, } \\
\text { zyklonal }\end{array}$ & $\begin{array}{l}\text { High pressure Norwegian } \\
\text { Sea-Fennoscandia, cyclonic }\end{array}$ \\
\hline 24 & SEA & & Anticyclonic & Südostlage, antizyklonal & Southeast wind, anti-cyclonic \\
\hline 25 & SEZ & & Cyclonic & Südostlage, zyklonal & Southeast wind, cyclonic \\
\hline 26 & SA & & \multirow{4}{*}{ Southerly } & Südlage, antizyklonal & South wind, anti-cyclonic \\
\hline 27 & SZ & & & Südlage, zyklonal & South wind, cyclonic \\
\hline 28 & TB & & & Tief Britische Inseln & Low pressure, British Isles \\
\hline 29 & TRW & & & Trog Westeuropa & Trough, Western Europe \\
\hline 30 & $\mathrm{U}$ & & - & Übergang/unbestimmt & Transition, no classification \\
\hline
\end{tabular}

The HB-GWL catalog contains the dominant CP types on a daily basis between 1881 and 2016 and was provided by PIK Potsdam. Although focusing on Central Europe, the HB-GWL was also found to be suitable for Turkey (personal communication with PIK representatives on 7 February 2019). Since it is the only daily weather classification system that covers the entire study period 1960-2014, we used the HB-GWL catalog for our study. 


\subsubsection{Digital Elevation Model (CGIAR-CSI SRTM, 90 m v.4)}

The Consortium for Spatial Information (CGIAR-CSI) provides high-resolution remote sensing imagery and spatially-explicit multidisciplinary datasets [43]. The Shuttle Radar Topographic Mission (SRTM) Digital Elevation Models (DEMs) were originally produced by the National Aeronautics and Space Administration (NASA) and are freely available for all over the world at a $90 \mathrm{~m}$ resolution at the equator, and mosaicked in $5^{\circ} \times 5^{\circ}$ tiles [44].

For this study, the SRTM $90 \mathrm{~m}$ DEM version 4.0 data were used to calculate the Infiltration Number (IN) and the catchment boundaries (TCA) (see Section 2.3.4 for details).

\subsubsection{Soil Map of Turkey (BTG, 1987)}

In Turkey, soil mapping studies began in the early 1930s and were improved at certain intervals in 1938, 1940, 1958, 1960, and 1975 [45]. The current soil map of Turkey was updated in 1987 by the Ministry of Forestry and Water Affairs based on FAO-UNESCO and Soil Taxonomy, considering topography (slope), soil depth, drainage properties, salinity and alkalinity of the soil, land use, vegetation and stand properties, and land use capability properties. These maps were digitized by the Ministry of Forestry and Water Affairs, Information Technology Department in 2013 [45]. The Soil Map of Turkey (BTG, Major Soil Groups, Büyük Toprak Grupları in Turkish) was used to determine the Infiltration Rate (IR) in the study areas (see Section 2.3.5).

\subsubsection{Corine Land Cover Data (CLC 2012)}

CORINE Land Cover (CLC) is a European project that was initiated by the European Environment Agency (EEA) and aims to regularly produce a consistent national land cover database including land cover changes for 39 countries in the European Economic Area by visual interpretation of high-resolution satellite imagery [46]. The CLC dataset includes 44 classes with a Minimum Mapping Unit (MMU) of 25 ha and is freely available in both raster (100 m resolution) and vector (ESRI and SQLite geodatabase) formats [47].

In the present study, the CLC 2012 dataset was used to calculate the proportion of the area with water bodies (WB) and artificial areas (industrial areas, urban areas, etc.), hereafter referred to as urbanized areas (UA).

\subsection{Methods}

In this study, we developed a new approach that allows us to evaluate the dominant factor of flood-aggravating mechanisms on a regional basis in Turkey using publicly accessible and free data sources. This approach was designed as a structured process, which uses the parameters selected based on the main causes and pathways of flooding and data availability.

Following the SPRC model in Figure 1, eight parameters were chosen to evaluate the dominant parameter of aggravating mechanisms for severe flood events: (1) PREC (Event Day Total Precipitation); (2) ACP (Atmospheric Circulation Pattern); (3) ASM (Antecedent Soil Moisture); (4) IN (Infiltration Number); (5) IR (Infiltration Rate); (6) UA (Share of Urbanized Areas); (7) WB (Share of Water Bodies; and (8) TCA (Total Catchment Area). These parameters were determined for the 25 events shown in Figure 3 and the 78 case studies (Appendix A, Table A1) mentioned above.

The determination of the parameters is presented in the following sections.

\subsubsection{Event Day Precipitation (PREC)}

Daily precipitation data were obtained from the TSMS, and 30-day time series were created by considering the reported day as the midpoint (i.e., the 15 days before the event, the reported event day, and the 14 days after the event) for 78 cases. With this approach, we aimed to see the antecedent conditions and the after the event day conditions, whether there were multiple peaks. The TSMS station data were taken as representative for each catchment. In the case that there were multiple stations in 
the catchments, the maximum precipitation amount was considered as representative. ERA5 daily precipitation data were also intersected with the time series to fill the data gaps. Daily precipitation amounts were derived from hourly data for the ERA5 data. Peak rainfall day was compared with the reported event day in TABB and EM-DAT databases using the consistent time series and cross-checked with related literature. Both datasets show consistency, especially in terms of peak rainfall days on time series. However, precipitation amounts are slightly different since ERA5 is modeled data. Therefore, the TSMS station data records were prioritized during the analysis. The reported event day was corrected if necessary based on rainfall peaks and literature information. The total precipitation amount of the corrected event day at the representative station was used as a PREC parameter for the cluster analysis.

\subsubsection{Determination of the Atmospheric Circulation Pattern Types (ACPs)}

Flood occurrence in large-scale areas is linked with atmospheric phenomena in general [30]. Therefore, it is important to determine the atmospheric circulation pattern types (ACPs) associated with the severe flood events in Turkey as a triggering factor. To achieve this objective, the Hess and Brezowsky Großwetterlagen catalog (HB-GWL, see Section 2.2.4) was used.

A 30-day period time series for each flood event was analyzed to specify the effective ACPs. The corrected event day (see Section 2.3.1) was considered as a reference to determine the decisive ACPs. Effective ACPs before the event and on the event day were compared with rainfall amounts at rainfall stations in the affected catchments and neighboring ones. The triggering ACP of the rainfall peaks (not the flood itself per se) was recorded for each event. However, ACP values were not included in the hierarchical clustering since they were non-numerical values, but these values were used to interpret the cluster results in terms of the main flood-generating circulation types in Turkey.

\subsubsection{Determination of the Antecedent Soil Moisture (ASM) Parameter}

Soil moisture is an important factor concerning the antecedent conditions of a flood event [48]. For large-scale catchments, remote sensing methods combined with simulation models are frequently used to determine the soil moisture, and a wide variety of studies using these methods are available. Nied et al. [48] implemented a spatiotemporal analysis of hydro-meteorological and remotely sensed radar data to understand the soil moisture pattern-flood occurrence relationship. Similarly, Brocca et al. [49] used scatterometer data to estimate antecedent wetness conditions. Most of the studies were carried out in small catchments. Furthermore, for improved models of antecedent soil moisture conditions, better data are essential (e.g., remote sensing data, discharge data, relative humidity, duration of sunshine, etc.). However, neither the time scale of the study (1960-2014) nor the size of the study area (entire Turkey, $783,562 \mathrm{~km}^{2}$ ) is suitable for these methods. Hence, another approach to estimate the antecedent soil moisture conditions was considered.

Özer [50] suggested a method to estimate the general antecedent soil moisture conditions using daily precipitation data. He classified the five-day cumulative daily total precipitation before the event day into three classes and assigned the pre-event soil conditions: (I) dry; (II) moderately saturated; and (III) saturated (Table 2).

Table 2. Precipitation limits for antecedent soil moisture estimation in Turkey [50].

\begin{tabular}{cccc}
\hline & & \multicolumn{2}{c}{$\begin{array}{c}\text { Five-Day (Before the Event) } \\
\text { Cumulative Daily Total Precipitation (mm) }\end{array}$} \\
\hline $\begin{array}{c}\text { Antecedent Soil } \\
\text { Moisture Class }\end{array}$ & $\begin{array}{c}\text { Antecedent Soil } \\
\text { Moisture Conditions }\end{array}$ & November-March & April-October \\
\hline I & Dry & $<12$ & $<36$ \\
II & Moderately Saturated & $12-28$ & $36-53$ \\
III & Saturated & $>28$ & $>53$ \\
\hline
\end{tabular}


The ASMs of the severe flood events were thus determined using Özer's [50] approach. Daily precipitation data from the 282 rainfall stations (Figure 4) were used to create areal precipitation maps by kriging. Five-day rainfall data before the event of each case were summed via overlapping areal daily precipitation data. For the areal rainfall data, the number of stations in and around the affected area was quite important for interpolation. However, the TSMS stations data contain too many data gaps (N/A value) for a good interpolation. Therefore, the ERA5 GRIB precipitation raster data were also used to fill the data gaps. Five-day cumulative daily total precipitation maps were reclassified according to Table 2. For each catchment, the percentage of areas with saturated soil conditions (Class III, Table 2) was calculated and used as an ASM parameter for the cluster analysis.

\subsubsection{Calculation of the Infiltration Number (IN) and the Total Catchment Area (TCA)}

Topography is one of the most important flood-generating factors [51]. Land use properties, drainage networks, and, accordingly, runoff characteristics of a catchment are influenced by topography [52]. Therefore, the analysis of morphometric parameters of a catchment for flood events plays an important role in understanding runoff dynamics.

Topography with its complex geomorphology heavily influences flood dynamics in Turkey. The orographic barrier effects of the Pontide Mountain Ranges in the north and the Tauride Mountain Ranges in the south, sudden height changes over short distances, and sudden snow melt during the spring season in the southeastern part of Turkey (Figure 5) can all be identified as flood-influencing mechanisms based on morphometric properties. Therefore, a numerical metric for the cluster analysis to show the comparative drainage properties of the catchment only based on topography was calculated for each event and used to reveal the geomorphological influence on flooding.

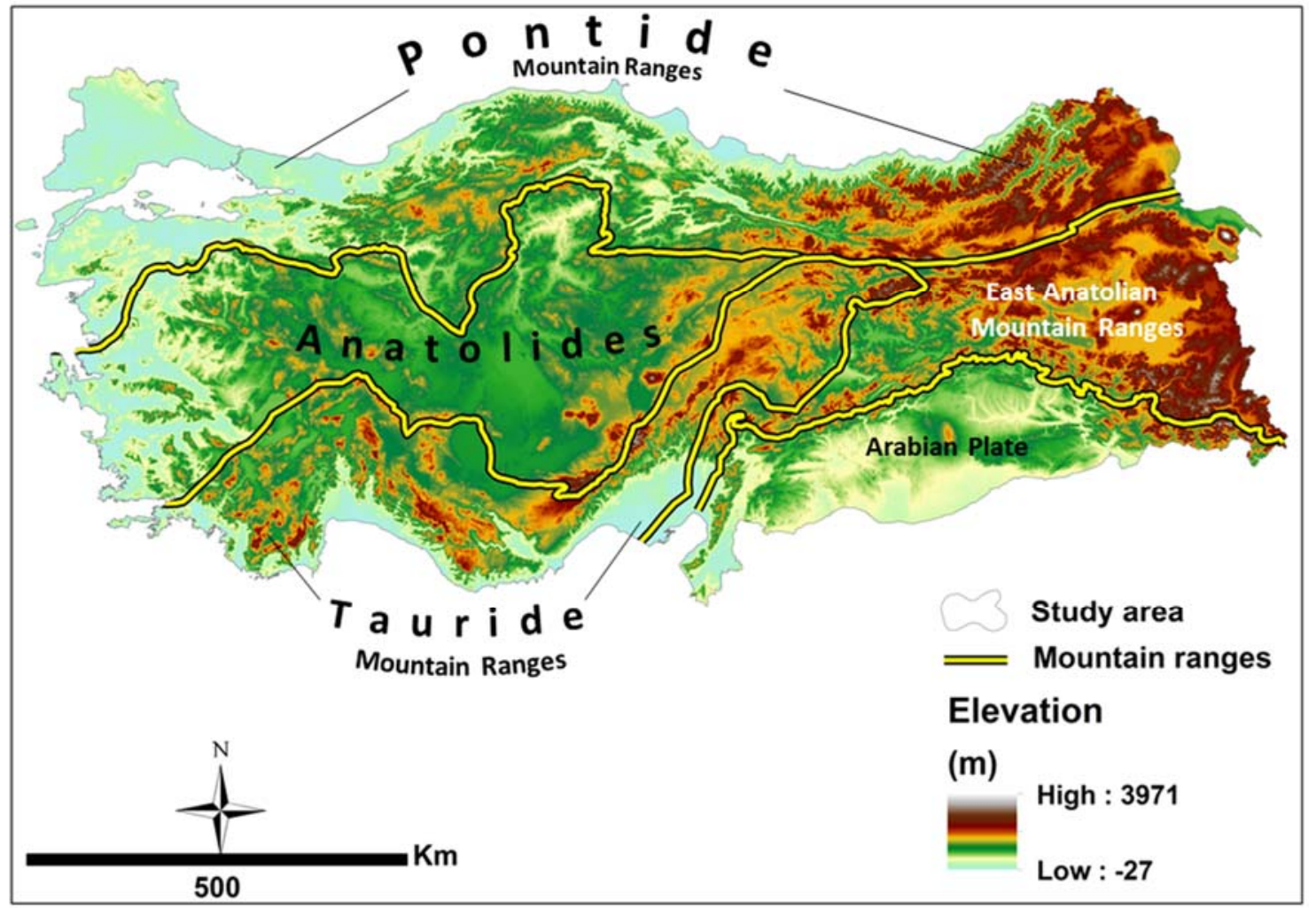

Figure 5. Elevation map and mountain ranges of Turkey (based on Shuttle Radar Topographic Mission, Digital Elevation Model; mountain range boundaries based on Candan et al. [53]).

The drainage characteristics play an important role in the time of concentration, and consequently runoff velocity, especially for flash floods, which are defined here following the TABB and EM-DAT 
as "rapid inland floods due to intense rainfall with short duration, which is typically associated with thunderstorms". The Infiltration Number (IN) captures such drainage characteristics and was therefore chosen as a parameter in this study.

The IN was developed by Faniran [54] and is defined by IN $=F_{s} \times D_{d}$, where $F_{s}$ is the stream frequency (no unit) and $D_{d}$ is the drainage density $\left(\mathrm{km} / \mathrm{km}^{2}\right)$, which gives information about the drainage texture of a watershed [52]. Drainage density $\left(\mathrm{D}_{\mathrm{d}}\right)$ and stream frequency parameters were calculated based on Horton's [55] approach. $\mathrm{D}_{\mathrm{d}}$ is defined as "the total streams of all orders to total drainage area" and formulated as $D_{d}=\sum L_{u} / A$, where $L_{u}$ is the stream length $(\mathrm{km})$ and $A$ is the total catchment area $\left(\mathrm{km}^{2}\right)$. $\mathrm{F}_{\mathrm{S}}$ is defined as the "number of stream segments per unit area" and formulated as $F_{\mathrm{s}}=\sum \mathrm{N}_{\mathrm{u}} / \mathrm{A}$, where $\mathrm{N}_{\mathrm{u}}$ is the number of stream segments (no unit) and $\mathrm{A}$ is the total catchment area $\left(\mathrm{km}^{2}\right)$ [52]. The term "stream segment" is defined as each segment of the stream, which is classified based on Strahler stream order, from the first order to maximum order [52], and calculated by the GIS Stream Order Tool (Strahler order method) in this study (Figure 6).

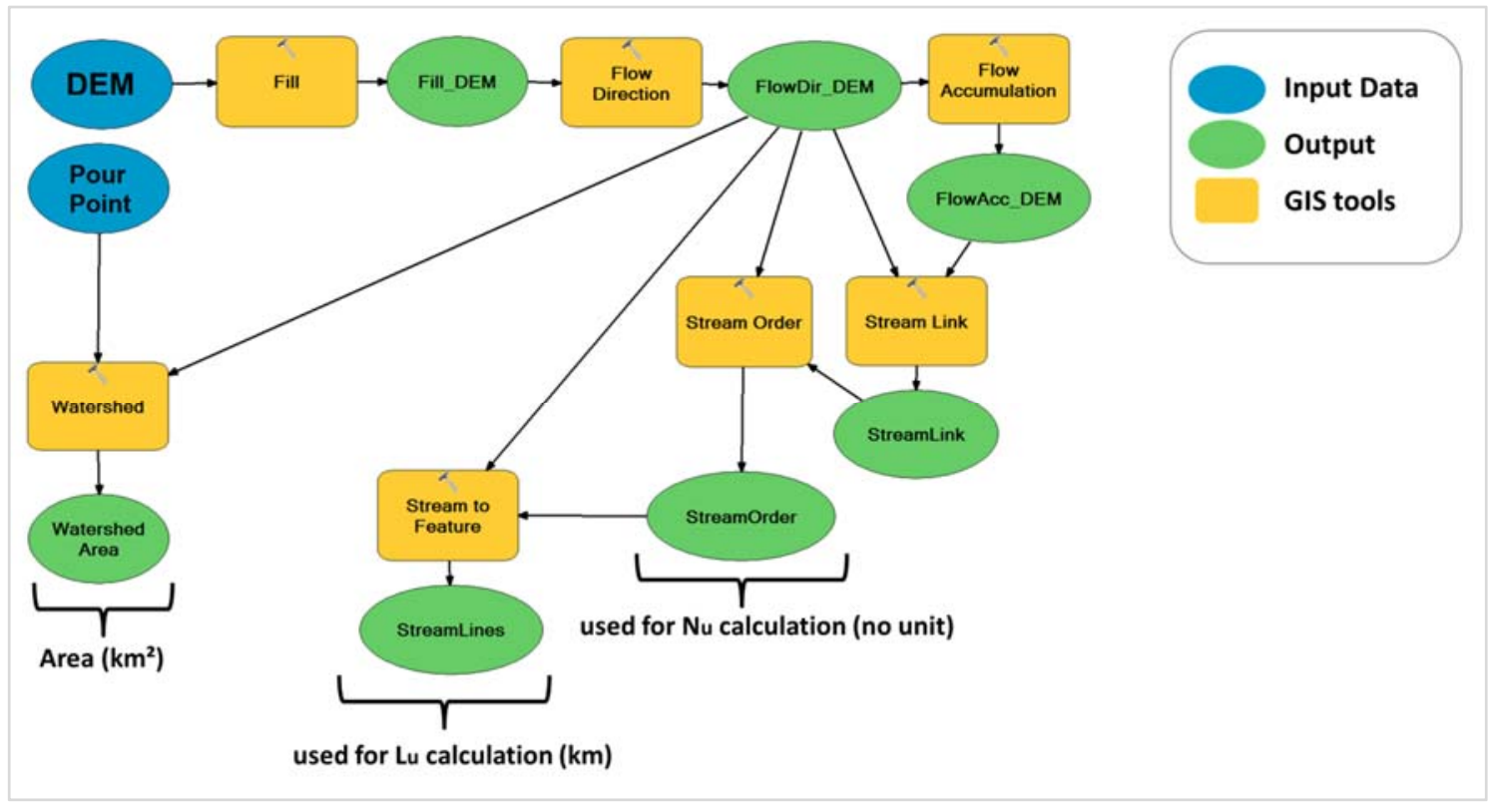

Figure 6. Conceptualized model of Infiltration Number (IN) and Total Catchment Area (TCA) calculation.

Based on the IN, comparative infiltration characteristics of the flood events can be assessed, whereby a higher IN means higher runoff and, accordingly, higher flood potential.

The IN calculation was implemented using Geographic Information Systems (GIS) tools (ArcGIS Software, Hydrology tool). An automatized calculation model was created by ArcGIS Model Builder (Figure 6) and each parameter of the IN factor was calculated for 78 cases (Appendix A, Table A1).

Additionally, the total catchment areas (TCAs) were also automatically derived from the SRTM DEM. The related publications and the news archives for the analyzed 25 events were used to cross-check and fill the data gaps in the TABB and EM-DAT datasets in terms of the affected districts. The affected districts of each province (Appendix A, Table A1) were used as pour points and catchments were automatically created using the GIS Watershed tool (Figure 6).

\subsubsection{Calculation of the Infiltration Rate (IR)}

The infiltration capacity of the soil affects the runoff volume in upstream catchment areas and, consequently, flood magnitudes of the catchment downstream in combination with its topographic factors [56]. Therefore, an analysis of soil properties is important for understanding runoff characteristics and the related pathways of flood hazards. For this purpose, the soil map of Turkey was used to derive a possible flood aggravating factor to be included in the cluster analysis. Özer [50] classified the Major 
Soil Groups of Turkey (BTG) in terms of their minimum infiltration rates by considering land use properties. He classified 23 major soil groups into four classes depending on their runoff potentials (Table 3 and Appendix A, Tables A2 and A3).

Table 3. Infiltration rate classification of hydrologic soil groups (Özer [50]).

\begin{tabular}{ccc}
\hline Hydrologic Soil Group & Runoff Potential & Minimum Infiltration Rate $\mathbf{~} \mathbf{m m} / \mathbf{h})$ \\
\hline A & Low & $7.5-10.0$ \\
B & Medium & $3.5-7.5$ \\
C & High & $0.8-3.0$ \\
D & Very high & $0.0-3.0$ \\
\hline
\end{tabular}

* Please see the Appendix A, Tables A2 and A3 for the detailed soil map unit symbols.

According to Özer's [50] classification, hydrologic soil groups provide information about the minimum infiltration rate of the soils. Therefore, Özer's [50] classification system was applied to the Turkish Soil Maps to calculate the IR factor of each event. For each catchment area, the percentage of the area with comparatively high infiltration rates (Hydrologic Soil Groups A and B, see Table 3) was calculated and used as the IR parameter for the cluster analysis.

As mentioned in Section 2.2.6, the soil map of Turkey was last updated in 1987. However, land use change is a dynamic process and land coverage might differ immensely at short time scales. Therefore, to eliminate the miscalculation of the area with high infiltration rate soils, the soil map was intersected with the CLC 2012 land use map, and urbanized areas were assigned as Hydrologic Soil Group D (Table 3). In so doing, the IR parameter was updated.

\subsubsection{Determination of Urbanized Areas (UA) and Water Bodies (WB) Parameters}

Land use is also important as a potential flood-influencing factor. With the land use changes (e.g., deforestation, drainage, urbanization, agricultural practices, etc.), soil moisture, infiltration properties, runoff characteristics, and water storage capability of the land can change significantly [57] and land use properties have a strong impact on flood events, as mainly controlled by human activities. Therefore, land use parameters were also included in the cluster analysis.

The artificial areas represented with CLC codes $1^{* *}(111,112,121,122,123,124,131,132,133,141$, and 142) provide information about the urban areas (CLC codes 111 and 112); industrial, commercial, and transport units (CLC codes 121,122, 123, and 124); mine, dump, and construction sites (CLC codes 131, 132 and 133); and artificial areas (i.e., recreational and leisure urban parks, and sport and leisure facilities) (CLC codes 141 and 142) [47]. The share of artificial areas in the CLC 2012 dataset was calculated for the 78 case studies and used for cluster analysis as the UA factor.

The water bodies represented with CLC codes $4^{* * *}$ and $5^{* *}(411,412,421,422,423,511,512$, 521, 522, and 523) provide information about the wetlands (CLC codes 411 and 412), water-courses serving as water drainage channels with minimum width of $100 \mathrm{~m}$ (i.e., natural water streams, rivers that are canalized, artificial canals, branching glacial rivers with dynamically changing courses, and interspersed gravel islands, where water surface in yearly average occupies $>50 \%$ of the area) (CLC codes 511 and 512), and marine waters (i.e., coastal lagoons, estuaries, sea, and oceans) (CLC codes 521, 522, and 523) [47]. The share of water bodies in the CLC 2012 dataset was also calculated and used for cluster analysis in order to capture the retention capacities of the catchments.

\subsubsection{Cluster Analysis}

Cluster analysis is a widely used, prevalent statistical tool for the natural sciences, such as biology, ecology, or atmospheric research fields [58-60]. Similarities or dissimilarities between the data points are measured and presented as distance in cluster analysis [61]. Cluster analysis is an unsupervised method, which means the input-output relation of the dataset is not given as a function. Unsupervised methods are used to cluster the dataset in cases where there is no knowledge of the 
relation between variables. Therefore, it is also important to select the proper cluster analysis type (e.g., connectivity-based, centroid-based, distribution-based, or density-based clustering) based on input-output dataset properties [62]. It is possible to summarize the input-output relation of the dataset we used as follows:

- There are no functional relations between the input parameters.

- There is no pre-cluster information.

- There is no areal cluster information.

Given the reasons listed above, the dataset is most suitable for the connectivity-based (hierarchical) clustering method. For the calculations, we used " $R$ " software, "agnes \{cluster\}" algorithm, and Euclidian distance, which is the most frequently used distance metric, especially in climatology [63]. The Euclidean distance $\left(\mathrm{d}_{\mathrm{E}}\right)$ between two observations $\mathrm{x}$ and $\mathrm{y}$, each with $\mathrm{n}$ variables, is determined by: $\mathrm{d}_{\mathrm{E}}(\mathrm{x}, \mathrm{y})=\sqrt{\sum_{\mathrm{i}=1}^{\mathrm{n}}\left(\mathrm{x}_{\mathrm{i}}-\mathrm{y}_{\mathrm{i}}\right)^{2}}$. Euclidean distance does not take into account the correlation between the variables and assigns equal weight to each variable [63]. Since there is no pre-information over the variables that are used for cluster analysis, Euclidean distance was selected to assign equal weight to each input variable.

To analyze the main aggravating mechanisms of severe flood events in Turkey, all parameters were clustered using hierarchical clustering and the complete-linkage method, which is known to create homogeneous clusters. The aim was to group similar parameters into the same cluster and to assess the dominant causal factor for each flood event. Before the implementation of the cluster analysis, all numeric parameters were standardized with the "scale" function. With this scaling, based on the standard score (also called as z-values or z-scores) method, we aimed to eliminate miscalculations due to unit differences.

\section{Results}

\subsection{Flood Types and Atmospheric Circulation Patterns (ACP)}

The 25 most severe flood events in Turkey between 1960 and 2014 were used as a starting point to analyze the main triggering factors for flood hazards. In this dataset, $40 \%(n=10)$ of the events occurred in summer. Flash floods were most frequent, at 64\% $(n=16)$ (Figure 7$)$.

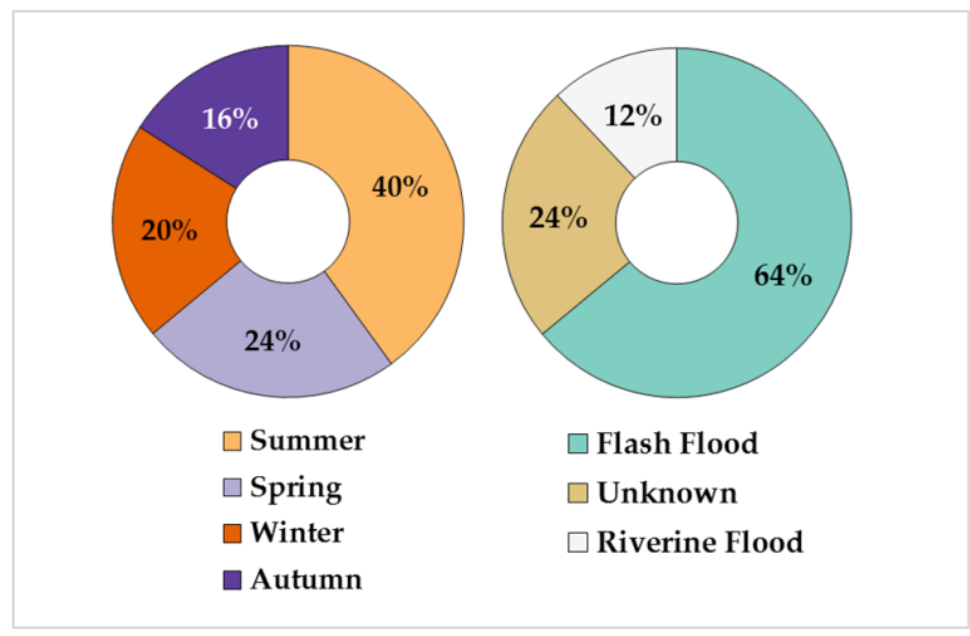

Figure 7. Type and seasonal frequency of the 25 most severe flood events (1960-2014).

When the 25 events were analyzed with regard to the associated ACPs, 14 out of the 30 ACPs were detected as triggers of at least one flood event. The BM (high pressure bridge over Central Europe, anticyclonic, see Table 1) circulation pattern takes first place with $16 \%(n=4)$ as a flood-triggering 
ACP, followed by the SWZ (Southwest wind, cyclonic) pattern with $12 \%(n=3)$. All other ACPs only triggered one or two events from our dataset.

To analyze the influence of the ACPs per season, we looked at the overarching form of circulations (see Table 1). Table 4 indicates that zonal, i.e., westerly, circulations do not play an important role in comparison to mixed or meridional circulations, with BM and SWZ being the important mixed circulations. It should be noted that half of the flood events studied that occurred in spring or summer were triggered by meridional circulations, whereas three out of four floods in autumn were triggered by mixed circulations (Table 4).

Table 4. Frequency of the most severe flood events' form of circulation in Turkey (1960-2014).

\begin{tabular}{lccccc}
\hline \multicolumn{7}{c}{ Number of Floods } \\
\hline Form of Circulation * & Winter & Spring & Summer & Autumn & Sum \\
\hline Zonal & 1 & 1 & 2 & 0 & $4(16 \%)$ \\
Mixed & 2 & 2 & 3 & 3 & $10(40 \%)$ \\
Meridional & 2 & 3 & 5 & 1 & $11(44 \%)$ \\
Sum & $5(20 \%)$ & $6(24 \%)$ & $10(40 \%)$ & $4(16 \%)$ & $25(100 \%)$ \\
\hline
\end{tabular}

* Please see Table 1 for circulation form of ACPs.

Since only 25 events were analyzed, the question arises as to how representative these findings are. Therefore, daily ACP data were used as supportive information for a better interpretation based on rainfall-producing frequencies to cross-check and determine the heavy precipitation as the dominant triggering factor.

According to the ACPs' long-term frequency analysis during 1960-2014 (data not shown), BM (high pressure bridge over Central Europe) and WZ (West wind, cyclonic) are the most frequent circulation pattern types that play a significant role as rainfall producing ACPs. They were also dominant for the analyzed 25 severe flood events. Furthermore, this analysis shows that the BM (high pressure bridge over Central Europe) circulation pattern is mostly responsible for the very high rainfall events, which is partly represented in terms of the ACP frequencies. According to the results, it might be interpreted that the BM (high pressure bridge over Central Europe) circulation pattern plays the significant role for autumn flash floods, while the SWZ-WZ (Southwest/West wind, cyclonic) mostly triggers summer flash floods in the 25 events we analyzed.

\subsection{Antecedent Soil Moisture (ASM) of the Most Severe Flood Events}

According to Özer's [50] approach, the antecedent soil moisture was calculated for each case ( $n=78$, Appendix A, Table A1), based on the five-day cumulative daily total precipitation before the event day. The share of the area with saturated soil conditions (Class III, Table 2), which provides information about the pre-event conditions of the flood events, was used as an ASM parameter for the cluster analysis. Accordingly, just $7.7 \%$ of all cases $(n=6)$ had completely saturated soil conditions in the entire catchment (saturated area rate in the catchment $=100 \%$ ) before the actual flood event occurred. Nevertheless, $82.1 \%(n=64)$ of all cases showed completely dry conditions before the flood events (saturated area rate in the catchment $=0 \%)($ Appendix A, Table A1, ASM).

\subsection{Infiltration Number (IN)}

The Infiltration Number (IN) of the 78 case studies was calculated based on Faniran's [54] method (see Section 2.3.4, Figure 6). IN is a unitless parameter that shows the comparative infiltration ability of the catchments only based on topography. According to the calculations, Erzurum province, part of Eastern Anatolia (see Figures 2 and 5 and FH11_06 in Appendix A, Table A1), has the maximum IN value with 9.33 and Isparta (Sütçüler) province, part of the Mediterranean region, has the minimum IN value with 1.03 (see Figures 2 and 5 and FH03_04 in Appendix A, Table A1). The average IN value for 
all catchments is 5.15 . The IN parameter is directly proportionate to runoff, which means the higher is the IN, the higher is the runoff and thus the resulting flood potential.

\subsection{Infiltration Rate (IR)}

Based on Özer's [50] classification, hydrologic soil groups that provide information about the minimum infiltration rates of soils were integrated with the Turkey Soil Map. For each catchment, the share of area with comparatively high infiltration rates (Hydrologic Soil Groups A and B, Table 3), which indicates a low surface runoff potential of the catchment, was determined (see Section 2.3.5).

According to the calculations, only one catchment $(1.3 \%, \mathrm{n}=1)$ had the highest percentage $(80-100 \%)$ of areas with high infiltration capacity soils. Overall, $8.9 \%$ of the catchments $(n=7)$ had a high percentage $(40-80 \%)$ and another $8.9 \%$ of the catchments $(n=7)$ had a moderate percentage $(20-40 \%)$ of areas with high infiltration capacity. The majority of the catchments $(60.3 \%, \mathrm{n}=47)$ had low percentages $(0-20 \%)$ and $20.5 \%$ of the catchments $(n=16)$ did not contain any soil type with high infiltration capacity $(I R=0 \%$, Appendix A, Table A1, IR).

\subsection{Cluster Results}

Hierarchical clustering (complete-linkage with Euclidean distance) was applied to assess the main aggravating mechanisms of the analyzed flood events (see Section 2.3.7). During the selection of the appropriate clustering method, input-output relations of the variables and their correlation coefficients (Figure 8) were considered: Since there is no significance correlation between the input variables or any functional relation, connectivity-based clustering was chosen.

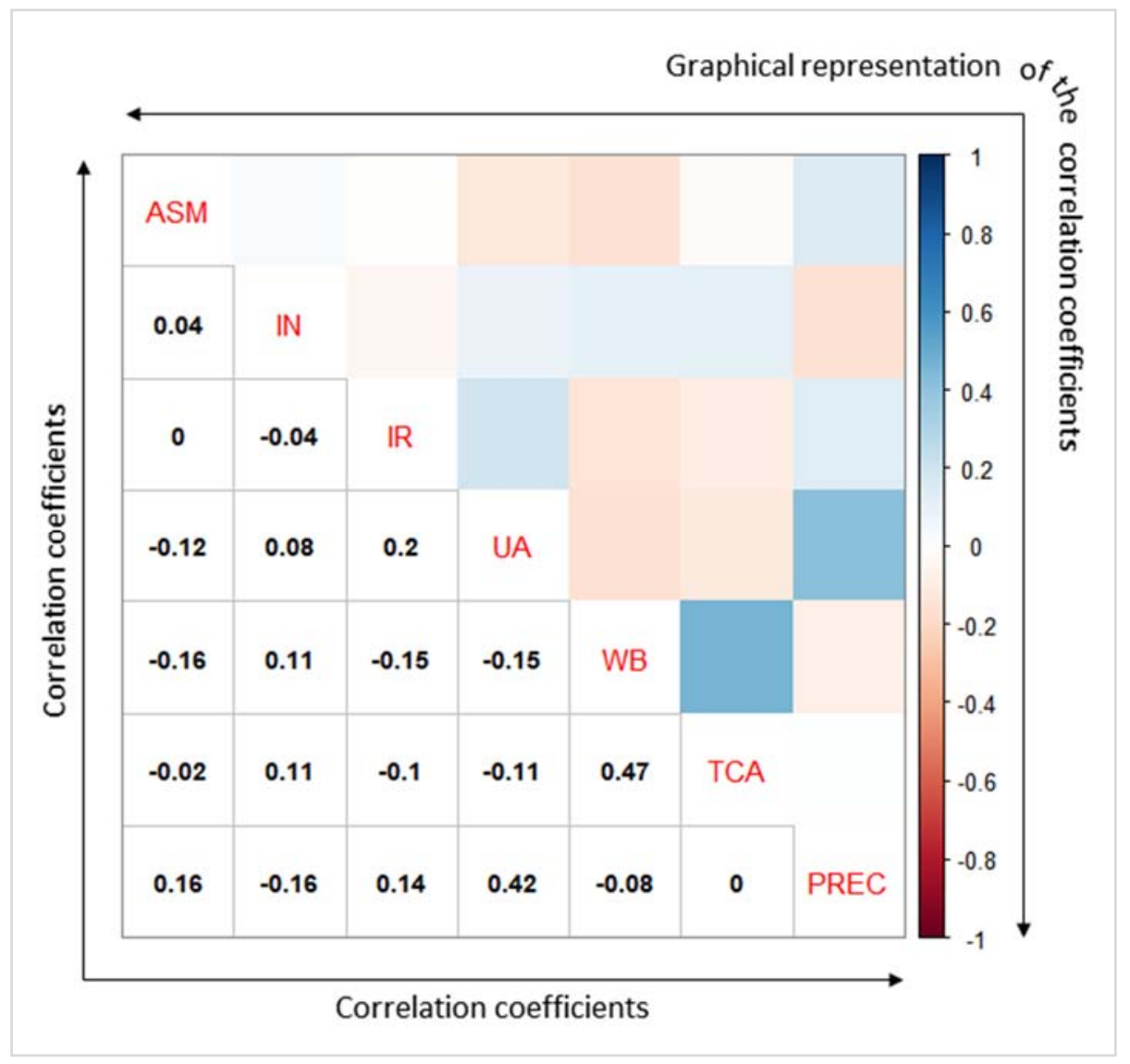

Figure 8. Correlation matrix of the input parameters.

According to the dendrogram (Appendix A, Figure A2), six clusters were defined; the sizes of the clusters were quite heterogeneous. Table 5 summarizes the characteristics of each cluster as mean 
values of the input variables. The results were mapped using ArcGIS (Figure 9), and thus the visual presentation allows us to analyze the spatial pattern of each cluster and helps us understand the flood-producing mechanism.

Table 5. Mean values of each cluster.

\begin{tabular}{|c|c|c|c|c|c|c|c|c|}
\hline Cluster No. & $\begin{array}{l}\text { Number } \\
\text { of Cases }\end{array}$ & $\begin{array}{c}\text { Mean } \\
\text { ASM (\%) }\end{array}$ & $\begin{array}{l}\text { Mean IN } \\
\left(\mathrm{km} / \mathrm{km}^{2}\right)\end{array}$ & $\begin{array}{c}\text { Mean IR } \\
(\%)\end{array}$ & $\begin{array}{c}\text { Mean } \\
\text { UA (\%) }\end{array}$ & $\begin{array}{c}\text { Mean } \\
\text { WB (\%) }\end{array}$ & $\begin{array}{c}\text { Mean TCA } \\
\left(\mathrm{km}^{2}\right)\end{array}$ & $\begin{array}{c}\text { Mean PREC } \\
\text { (mm/day) }\end{array}$ \\
\hline 1 & 2 & 0.10 & 5.78 & 1.61 & 0.95 & 4.08 & $46,854.60$ & 59.85 \\
\hline 3 & 5 & 0.00 & 8.00 & 5.76 & 11.54 & 0.09 & 559.90 & 37.34 \\
\hline 4 & 5 & 4.90 & 4.43 & 64.62 & 20.42 & 0.61 & 56.50 & 133.36 \\
\hline 5 & 9 & 92.23 & 5.30 & 11.89 & 1.39 & 0.25 & 2062.18 & 86.47 \\
\hline Overall Mean & 78 cases & 11.92 & 5.15 & 13.05 & 6.64 & 0.80 & 2422.70 & 59.50 \\
\hline
\end{tabular}

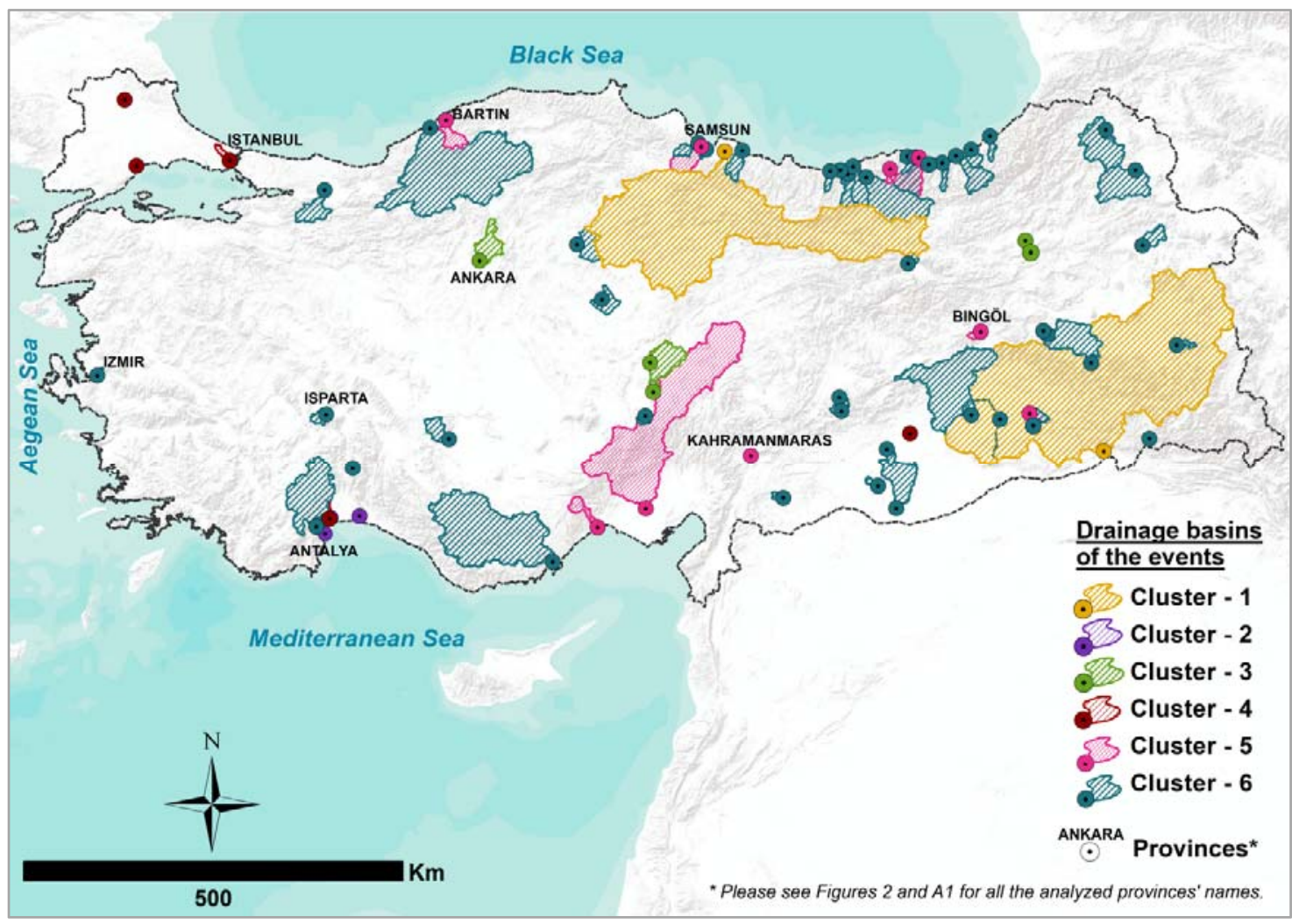

Figure 9. Spatial distribution of clusters.

Cluster 1 contains only two cases, and they are clustered mainly based on their very high TCA and high WB values. The mean catchment area in Cluster 1 amounts to $46,854.60 \mathrm{~km}^{2}$ and the mean share of WB is $4.08 \%$ (Table 5). In addition to the large catchment size and shape factors, rapid change in the elevation over short distances (see Figure 5) probably also plays an important role for runoff characteristics in this cluster. Şırnak province in southeastern Anatolia (see Figures 2 and 5 and FH10_01 in Appendix A,Table A1) and Samsun (Çarsamba) province in the Black Sea region (see Figures 2 and 5 and FH24_01 in Appendix A, Table A1) have high IN values due to their drainage properties; furthermore, rapid elevation changes (slope gradient changes) in these regions (see also Figure 5) along with the size and shape factors of the catchments aggravate the flood events (Table 5 and Figure 9). When the ACPs were analyzed for this cluster, it was revealed that both events were triggered by SWZ-WZ (Southwest/West wind, cyclonic) circulation pattern types. 
Cluster 2 also contains two cases with very high UA (mean UA $=86.82 \%$ ), very high precipitation (mean PREC $=210 \mathrm{~mm} /$ day) values, and small catchment areas $\left(\right.$ mean TCA $\left.=6.95 \mathrm{~km}^{2}\right)$. Since both catchments were affected by the same flood event (November 1995 flood event, Appendix A, Table A1), ACPs for both cases are NZ (North wind, cyclonic). High urbanization rates in small catchments change the land use properties and, accordingly, decrease the infiltration rate substantially in Cluster 2. Both cases in this cluster are located in the Mediterranean region (Figure 9) and urbanization was determined to be the main aggravating factor.

Cluster 3 contains five cases, where a high infiltration number (IN), i.e., high topographic factor, is the striking feature (mean IN $=8.00 \mathrm{~km} / \mathrm{km}^{2}$, Table 5). All cases are located in central and eastern Anatolia, where the steep topography is dominant (Figure 9). Nevertheless, no dominating ACP type was identified for this cluster (Appendix A, Table A1), but all events occurred in spring or summer.

In Cluster 4, extreme rainfall events were determined as the main triggering mechanism (mean PREC $=133.36 \mathrm{~mm} /$ day). Although the catchments in Cluster 4 show a high infiltration rate (mean $\mathrm{IR}=64.62 \%, \mathrm{n}=9$ ), heavy precipitation totals and high rainfall intensity $(14.6 \mathrm{~mm} / \mathrm{h})[64,65]$ are considered the main factors in the severity of these events. BM (high pressure bridge over Central Europe) is the dominant ACP for this cluster, which was one of the most frequent rainfall-producing circulation pattern types in Turkey between 1960 and 2014 (see Section 3.1).

Cluster 5 contains nine cases that have very high ASM values (mean ASM =92.23\%). In Cluster 5 , basically pre-event conditions are the main influencing factor. Very high antecedent soil moisture (mean ASM = 92.23\%, Table 5) and, accordingly, low infiltration capacity is the pathway of the flood hazards in this cluster. No dominant ACP type or season was identified for this cluster (Appendix A, Table A1).

Cluster 6 comprises the highest number of events $(n=55$, Table 5); consequently, no specific dominant influencing factor could be identified. However, the spatial distribution of the events in Cluster 6 indicates a direct relation to the mountain ranges of Turkey (compare Figures 5 and 9); the Tauride Mountain Ranges in the south, Pontide Mountain Ranges in the north, East Anatolian Mountain Ranges in the east, and Anatolides in central Anatolia (Figure 5). This situation illustrates the orographic barrier effect in these areas. Thus, the aggravating factor for these events can be regarded as a combination of orographic rainfall and topographic factors.

In summary, each cluster is characterized as follows:

Cluster 1: Main aggravating factor: Drainage Properties (i.e., size, shape and soil type)

- Dry pre-conditions, very low antecedent soil moisture (mean ASM $=0.10 \%$ )

- Very low infiltration capacity, very low infiltration rate (IR) (mean IR $=1.61 \%$ )

- $\quad$ Very large catchment size (mean TCA $=46,854.60 \mathrm{~km}^{2}$ )

- Comparatively high percentage of area with water bodies (mean WB $=4.08 \%$ )

Cluster 2: Main aggravating factor: Urbanization

- Dry pre-conditions, very low antecedent soil moisture (mean ASM $=0.00 \%$ )

- $\quad$ Very high percentage of urbanized area (UA) (mean UA=86.82\%)

- Very small catchment area (TCA) (mean TCA $\left.=6.95 \mathrm{~km}^{2}\right)$

- $\quad$ Extreme rainfall (mean PREC $=210 \mathrm{~mm} /$ day)

Cluster 3: Main aggravating factor: Topography

- Dry pre-conditions, very low antecedent soil moisture (mean ASM $=0.00 \%$ )

- Very high topographic factor, infiltration number (IN) (mean IN $=8.00 \mathrm{~km} / \mathrm{km}^{2}$ )

- High rainfall intensity (this information was obtained from the related literature (Cluster 3 [66])).

Cluster 4: Main aggravating factor: Extreme rainfall 
- $\quad$ Dry pre-conditions, low antecedent soil moisture (mean ASM $=4.90 \%$ )

- Low topographic factor, infiltration number (IN) (mean IN $=4.43 \mathrm{~km} / \mathrm{km}^{2}$ )

- Very high infiltration capacity, very high infiltration rate (IR) (mean IR $=64.62 \%$ )

- Extreme rainfall (mean PREC $=133.36 \mathrm{~mm} /$ day)

Cluster 5: Main aggravating factor: Saturated soil conditions

- $\quad$ Very high antecedent soil moisture (mean ASM $=92.23 \%$ )

- Comparatively low infiltration rate (IR), high runoff (mean IR $=11.89 \%$ )

- High rainfall (mean PREC $=86.47 \mathrm{~mm} /$ day)

Cluster 6: Main aggravating factor: Orographic effect of mountain ranges

- $\quad$ Spatial distribution over the mountain ranges

- Sudden snow melt through Eastern Anatolian Mountain Ranges (this information was obtained from the related literature (Cluster 6 [67-71])).

\section{Discussion}

The study aimed to understand the main aggravating mechanisms of the severe flood events in Turkey between 1960 and 2014. Event Day Precipitation (PREC), Atmospheric Circulation Patterns (ACP), Antecedent Soil Moisture (ASM), Infiltration Number (IN), Infiltration Rate (IR), Urbanized Areas (UA), Water Bodies (WB), and the Total Catchment Area (TCA) were considered to reflect important flood-causing factors. We were able to create one representative parameter for each causal factor using freely accessible datasets. The direct or indirect relevance of atmospheric circulation, precipitation patterns, and catchment properties (topography, soil, and land use) on the severe flood events in Turkey between 1960 and 2014 were investigated and used to cluster the events. As a result, six different clusters were retrieved and their properties were defined. To check the validity of this methodology, a few case studies were selected to cross-check the cluster results with the literature.

Cluster 1's definition indicates that drainage properties of the catchment are the main influencing factor for the flood events in this cluster. The cases in Cluster 1 have very large catchment sizes and very low infiltration capacities (Table 5). To verify this statement, the flood event in May 2000 in Samsun province (Figure 2, FH24_01, Appendix A, Table A1) was selected as being representative because its parameter values were similar to the mean values of Cluster 1. Based on the related literature, this event was triggered mainly by heavy rainfall and saturated soil conditions. The clustering results show that low infiltration capacity might explain the saturated soil conditions. However, ASM values do not reflect the saturated soil conditions for Cluster 1 . When we analyzed the related literature further, it indicated that the underground water table in the catchment was high [72]. Since ASM parameters were calculated only based on five-day cumulative precipitation amounts before the event day, the influence of high water table conditions on saturation could not be reflected. Nevertheless, low infiltration capacities are reflected in IR values of the catchment for Cluster 1 (Table 5 and Appendix A, Table A1). Taking all this information into account, it is possible to state that drainage properties (i.e., catchment size and shape, and soil type) are the most important aggravating factor for Cluster 1.

For the Antalya flood event in November 1995 (Figure 2, FH03_02 and FH03_03 in Appendix A, Table A1, and Cluster 2), Kömüscü et al. [73] indicated that Antalya province was affected due to cyclonic weather conditions, which influenced a larger region called the Mediterranean catchment. However, cluster analysis results show that the FH03_02 and FH03_03 catchment areas are quite small (mean catchment area $=6.95 \mathrm{~km}^{2}$ ) and the mean urban area (M-UA) percentage is high (M-UA $\left.=86.82 \%\right)$. In these two small catchments, it might be interpreted that unplanned urbanization occurred in parallel with low infiltration/high runoff. Furthermore, heavy precipitation is the triggering factor for these cases; exposed assets in the affected areas might drive the damage to a bigger extent in small catchments. The flooded regions that belong to Cluster 2(FH03_02 and FH03_03, Appendix A, Table A1) 
have a high share of urbanized areas in very small catchments. Yllmaz [74] reported that livestock industry facilities and greenhouses comprise the main share of the urban areas in these catchments and were heavily affected by the November 1995 flood event in economic terms. This clustering information could be very useful for land use planning (such as planned urbanization, infrastructure improvement, and determination of cattle-shed/greenhouse area/type) and flood prevention studies (such as flood-zoning) [75], in terms of defining the hazard pathway (Figure 9 and Table 5) to reduce the flood risk. Izmir and Isparta provinces (Figure 2) were also affected by the same flood event (FH03_01 and FH03_04, Appendix A, Table A1); however, due to their lower share of urban area $\left(\mathrm{UA}-\mathrm{FH} 03 \_01=25.93 \%\right.$ and UA-FH03_04 $=14.35 \%$, Appendix A, Table A1), UA factors were not defined as the main aggravating mechanisms for these cases and they were grouped into Cluster 6 .

Very high infiltration numbers (mean IN $=8.00 \mathrm{~km} / \mathrm{km}^{2}$ ) and thus the topography was determined as the main aggravating factor for Cluster 3. The June 1988 flood event (FH14_01, Appendix A, Table A1) was selected as representative for this cluster due to its parameter values, which are close to the sample average values of Cluster 3. Although the catchments in Cluster 3 have dry pre-conditions (mean ASM $=0 \%$ ), a high topographic factor (IN) in combination with high rainfall intensity $([66,76])$ caused the flood event in Ankara (Figure 2). All cases in Cluster 3 are located in Central and Eastern Anatolia (Figures 2 and 9 and Appendix A, Table A1), where flash floods in spring and summer are dominant due to sudden elevation changes over short distances.

Cluster 4's definition indicates that these events were triggered mainly by heavy rainfall (mean PREC $=133.36 \mathrm{~mm} /$ day) despite good infiltration rates of the soils (mean $I R=64.62 \%$ ). When the related literature was analyzed for Cluster 4, heavy rainfall which was much higher than the seasonal averages was identified as the main triggering factor for FH06_03 (Appendix A, Table A1) [64]. Similarly, Kömüscü et al. [65] and NOAA [77] indicated that FH08_01 and FH08_02 events (Appendix A, Table A1) were triggered by two full days of torrential rainfall, which was the highest amount in 80 years. Another case in Cluster 4, FH17_03 (Appendix A, Table A1), was also triggered by large-scale heavy rainfall which affected all of Turkey and the Balkans according to a NOAA report [78] and newspaper archives [79-83]. Yilmaz [74] reported that the December 1997 Antalya flood event (Figure 2 and FH22_01 in Appendix A, Table A1) was triggered by orographic heavy rainfall as well, which is also grouped into Cluster 4. Event definitions in the related literature verify and show obvious consistency with cluster results, therefore the main triggering mechanism for Cluster 4 was determined to be heavy rainfall. When the cases in this cluster were analyzed in terms of ACP types, BM (high pressure bridge over Central Europe) dominates the ACPs for Cluster 4. As also presented in Section 3.1, it is possible to interpret the BM (high pressure bridge over Central Europe) as playing an important role as a rainfall-producing circulation pattern type in Turkey.

According to the cluster analysis, saturated soil conditions were identified as the main aggravating factor for Cluster 5. To cross-check the consistency of the results, the related literature was analyzed. Artan [84] indicated that the December 1968 flood event (FH01_01 and FH01_02, Cluster 5, Appendix A, Table A1) was triggered by a month of precipitation, which caused saturated soil conditions before the event. Similarly, when the literature on the FH05_01 and FH05_04 cases (Appendix A, Table A1, Cluster 5) are analyzed, it is possible to see that these events also comprised three days of orographic rainfall mainly caused by a frontal system that was brought about by northerner cold and southerner hot weather conditions [85]. Due to the saturated conditions, debris flow was also caused in these regions [85]. FH06_10, FH12_01, FH12_02, FH16_01, and FH19_03 (Appendix A, Table A1, Cluster 5) cases were also aggravated by saturated soil conditions due to prolonged rainfall. Batman province (Figure 2, FH06_10) was heavily affected by heavy rainfall, which continued for six days [64]. Kahramanmaras and Bingöl provinces (Figure 2, FH12_01 and FH12_02) were flooded due to the three-day prolonged torrential rainfall [86]. Similarly, Samsun province (Figure 2, FH16_01) was affected by heavy rainfall, which continued for three days as well [87]. Ceylan et al. [67] and Cellek [88] indicated that prolonged rainfall occurred before the May 1998 Bartin flood event (Figure 2, FH19_01), which caused saturated soil conditions and an increase of Bartin Creek water levels. ASM values in each case (Table A1, ASM) 
and also the mean ASM value (mean ASM = 92.26\%) of Cluster 5 are consistent with the literature: high antecedent soil moisture based on prolonged rainfall can be determined as a pathway, and a new rainfall event over highly saturated soil conditions can be determined as the source and main triggering factor behind the flood events.

Cluster 6 contains many cases $(n=55)$ and each of them has different characteristics. Summer flash floods dominate Cluster $6(n=28$, Appendix A, Table A1). No dominant aggravating factor could be identified for this cluster. However, when the cases were mapped, it was revealed that Cluster 6 comprises mainly large-scale events in terms of affected areas. Each event in Cluster 6 caused floods in more than one sub-basin in different geographic regions in Turkey (see Figures 2 and 9). Different characteristics (e.g., region, flood type, and clustered parameters) and a wide range of spatial distributions based on geographic region can be interpreted to conclude that Cluster 6 events were triggered by comparatively larger-scale atmospheric circulations that affect larger areas regardless of region, topography, or land use properties. Nevertheless, the spatial distribution of the events in Cluster 6 shows consistency with the mountain ranges of Turkey (Figures 5 and 9). The orographic barrier effects in the northern, southern, and eastern parts of Turkey due to the Pontides, Taurides, and East Anatolian Mountain Ranges are the main influencing factor for severe flood events in these regions $[74,85,89]$. Another interesting outcome for the Cluster 6 event analysis is that sudden snow melt is the main influencing mechanism for all the cases located throughout the Eastern Anatolian Mountain Ranges (Eastern and Southeastern Anatolia and Eastern Black Sea regions, Figures 2 and 5) $(n=11)$, and these cases occurred in spring/summer. Since both TSMS and ERA5 rainfall data include the snowfall amounts in water equivalents [28,29], the cluster results do not reflect the direct impact of sudden snowmelt. Therefore, this information was obtained from the related literature [67-71].

When the clustering results were compared with the previous studies based on atmospheric circulation and precipitation pattern classifications in Turkey (e.g., [12,14]), Cluster 2 is in accordance with the Southern Aegean and Western Mediterranean (SAEG-WMED) precipitation region based on Türkes and Tatli's [12] classification, which affects particularly the coastal regions in the western Mediterranean. Cluster 3 shows consistency with the East Continental Central Anatolia (ECCAN) precipitation region, which influences continental central Anatolia with convective events. Based on Türkes and Tatli's [12] classification, Cluster 6 comprises the Black Sea (BLS), Continental Eastern and Southeastern Anatolia (CEAN-CSEAN), and Mediterranean (MED) precipitation regions, which were triggered by orographic lifting over the Taurus, East Anatolian and North Anatolian Mountain Ranges (see Figures 5 and 9). Clusters 1, 4, and 5 do not show direct consistency with Türkes and Tatli's [12] classification results. When the results were compared with the classification proposed by Saris et al. [14], Cluster 3 was in accordance with the Inland Regimes class, which was defined as a rainy spring period and characteristic convective rains [14]. Cluster 6 shows consistency with the Coastal Regimes class, which was defined as being consistently controlled by cyclogenesis and orographic rains [14]. The other clusters cannot be directly linked with the classification by Saris et al. [14]. Since these classifications are only based on precipitation data, aggravating factors such as topography, urbanization, or drainage properties cannot be reflected.

The cluster results also give important information about the Source-Pathway-ReceptorConsequence (SPRC) model elements of the flood hazards in Turkey, which are summarized in Table 6.

While the results of Clusters 1, 2,3, and 5 give information about the pathways of the flood events that aggravate the consequences, the results of Clusters 4 and 6 reflect the sources of the events and do not provide clear information about the pathways. Consequently, the main triggering mechanisms for Clusters 1, 2, 3, and 5 can be characterized by their different aggravating pathways. 
Table 6. Source-Pathway-Receptor-Consequence (SPRC) model elements of the clusters.

\begin{tabular}{|c|c|c|c|c|}
\hline Cluster & Source & Pathway & Receptor & Damage \\
\hline 1 & $\begin{array}{l}\mathrm{ACP}(\mathrm{SWZ} / \mathrm{WZ}) \\
\text { Frontal (Cyclonic) } \\
\text { rainfall }\end{array}$ & $\begin{array}{l}\text { Catchment } \\
\text { properties * }\end{array}$ & \multirow{6}{*}{$\begin{array}{c}\text { People } \\
\text { Settlement properties } \\
\text { Business } \\
\text { organizations }\end{array}$} & \multirow{6}{*}{$\begin{array}{c}\text { Human loss, health } \\
\text { impacts } \\
\text { Economic loss, } \\
\text { property damage }\end{array}$} \\
\hline 2 & $\begin{array}{l}\text { Frontal (Cyclonic) } \\
\text { rainfall }\end{array}$ & $\begin{array}{l}\text { Land use properties } \\
\text { (high share of } \\
\text { urbanized area)* }\end{array}$ & & \\
\hline 3 & $\begin{array}{l}\text { Convective rainfall } \\
\text { ACP }(\mathbf{B M}) *\end{array}$ & Topography * & & \\
\hline 4 & $\begin{array}{l}\text { Frontal (Cyclonic) } \\
\text { rainfall * }\end{array}$ & - & & \\
\hline 5 & $\begin{array}{l}\text { Frontal (Cyclonic) } \\
\text { rainfall } \\
\text { ACP * }\end{array}$ & $\begin{array}{l}\text { High antecedent } \\
\text { soil moisture * }\end{array}$ & & \\
\hline 6 & $\begin{array}{l}\text { Orographic rainfall * } \\
\text { Sudden snowmelt * }\end{array}$ & - & & \\
\hline
\end{tabular}

* Bold indicates the SPRC model elements identified via cluster analysis.

\section{Conclusions}

In this study, the triggering mechanisms and aggravating pathways of the 25 most severe flood events in Turkey were analyzed in terms of the atmospheric circulation pattern types, precipitation patterns, and catchment properties (topography, catchment size, land use types, and soil properties). A new approach was developed to investigate which of these parameters were possibly the main influencing factors leading to the high flood impacts. For this methodology, eight parameters were determined and calculated. Then, these 25 events with 78 cases (i.e., affected areas) were classified via hierarchical cluster analysis using seven of these parameters. The ACP parameter was used as supportive information to the cluster results. As a result, six different clusters were identified and interpreted with regard to the dominant influencing factors of the floods within that cluster. The resulting implications and limitations can be summed up as follows:

- A structured approach to classify floods was designed, using parameters chosen based on their potential triggering and aggravation factors.

- All input variables were obtained and calculated from freely accessible data.

- According to the cluster analysis, six clusters were found based on their dominant flood-producing factors.

- Mapping the clusters also provided the opportunity to interpret the results better in terms of the spatial distribution of the triggering mechanisms and aggravating pathways based on region.

- Orographic rainfall and sudden snow melt were important influencing factors for spring/summer floods in the regions that extend along the Eastern Anatolian Mountain Ranges.

- In central and eastern Anatolia, rapid elevation changes (slope gradient changes) over short distances aggravated the flood events. Geomorphological properties were the relevant factor for floods in these regions.

- The BM (high pressure bridge over Central Europe) circulation pattern type played an important role as a rainfall-producing mechanism, especially for autumn flash floods in Turkey.

- In small catchments, the share of urbanized areas seemed to be an important factor for the flood impacts, with its infiltration attenuation impact. Therefore, planned urbanization in the small catchment is of great importance for flood risk mitigation studies.

- Cluster results can be used as base information; clustering of the dominant flood-producing mechanisms can help hazard classification (source and pathway identification, in particular) in the preliminary risk assessment process.

- However, 25 events are only a small number of case studies and do not represent the entire variety of flood events and their triggering mechanisms. More detailed analyses with more case studies 
would be a useful next step in understanding the atmospheric circulation pattern impacts on flood events in Turkey. Furthermore, ASM parameter calculations are only based on precipitation and do not reflect the antecedent soil moisture due to underground water table levels or irrigation.

- $\quad \mathrm{UA}$ and WB parameters should be calculated based on event day land-use data.

- Additional datasets (such as runoff volume, flood extent, and depth) can be integrated into the cluster analysis. This methodology can be improved with a detailed dataset on event-based calculations and can provide basic information for understanding the triggering mechanisms and aggravating pathways of the flood events.

This study investigated and clustered the direct or indirect relevance of atmospheric circulation, precipitation patterns, and catchment properties for the severe flood events and SPRC model elements of these events in Turkey, between 1960 and 2014. The spatial distribution of clusters gives important information about the dominant triggering mechanisms on the regional scale. The classification of the floods can be useful for selecting mitigation types. For example, structural mitigation studies on, e.g., floodplain and river restoration might be conducted in the catchments where drainage characteristics (e.g., Cluster 1) and topography (e.g., Cluster 3) are the main aggravating pathways. Existing infrastructure can be maintained (e.g., creek clearing, storm-water drainage systems, etc.) in the catchments where the share of urban area is high. Furthermore, the roads can be improved to provide better access to hospitals or evacuation areas in the case of a severe flood event, especially in urbanized areas (e.g., Cluster 2). In addition to structural mitigation studies, non-structural mitigation practices can be implemented: early warning systems or household emergency plans might be developed in the catchments where the events can be predicted periodically (e.g., sudden snowmelt during spring/summer in Eastern and Southeastern Anatolia, Cluster 6).

This study can be useful for event definition and classification in flood risk management studies in order to understand the main causal factors and aggravating pathways affecting the selection of suitable mitigation practices.

Author Contributions: Conceptualization, G.K., T.P., and A.H.T.; Formal analysis, G.K.; Writing-original draft preparation, G.K.; Writing - review and editing, G.K., T.P., and A.H.T.; and Supervision, A.H.T. All authors have read and agreed to the published version of the manuscript.

Funding: This study was undertaken as part of the initial training network "ALErT: Anatolian pLateau climate and Tectonic hazards", funded as part of the European Union (EU) Marie Curie Actions program "Initial Training Networks (ITN)" under grant agreement FP7-PEOPLE-2013-ITN (No. 607996). We acknowledge the support by the German Research Foundation (Deutsche Forschungsgemeinschaft-DFG) and University of Potsdam Open Access Publishing Fund.

Acknowledgments: We would like to thank Peter Hoffmann (Potsdam Institute for Climate Impact Research (PIK)) and Ümit Koç (Hydrogeologist, University College London (UCL)) for sharing their valuable comments that greatly helped improve the study.

Conflicts of Interest: The authors declare no conflict of interest. 


\section{Appendix A}

Table A1. Most severe flood events in Turkey (1960-2014) and analyzed flood-triggering factors.

\begin{tabular}{|c|c|c|c|c|c|c|c|c|c|c|c|c|c|c|c|c|}
\hline \multirow[b]{2}{*}{$\begin{array}{l}\text { Event } \\
\text { Number }\end{array}$} & \multirow[b]{2}{*}{ Case ID } & \multirow[b]{2}{*}{$\begin{array}{l}\text { Case } \\
\text { Number }\end{array}$} & \multicolumn{4}{|c|}{ General Information } & \multirow[b]{2}{*}{$\begin{array}{l}\text { Corrected Event } \\
\text { Date } \\
\text { (Day-Month-Year) }\end{array}$} & \multirow[b]{2}{*}{$\begin{array}{l}\text { PREC }^{1} \\
\text { (mm/day) }\end{array}$} & \multirow[b]{2}{*}{$\mathrm{ACP}^{2}$} & \multirow[b]{2}{*}{$\begin{array}{c}\text { ASM }^{3} \\
(\%)\end{array}$} & \multirow[b]{2}{*}{$\underset{\left(\mathrm{km} / \mathrm{km}^{2}\right)}{\mathrm{IN}^{4}}$} & \multirow[b]{2}{*}{$\operatorname{IR}^{5}(\%)$} & \multicolumn{2}{|c|}{ Land Use Information } & \multirow[b]{2}{*}{$\begin{array}{l}\text { TCA } \\
\left(\mathrm{km}^{2}\right)\end{array}$} & \multirow[b]{2}{*}{$\begin{array}{c}\text { Cluster } \\
\text { No. }\end{array}$} \\
\hline & & & $\begin{array}{c}\text { Event Date } \\
\text { (Day-Month-Year) }\end{array}$ & $\begin{array}{l}\text { Event } \\
\text { Season }\end{array}$ & Geographic Region & $\begin{array}{l}\text { Flood } \\
\text { Type }\end{array}$ & & & & & & & $\begin{array}{c}\mathrm{UA}^{6}(\%) \\
\left(\operatorname{CLC}^{7} 1^{* *}\right)\end{array}$ & $\begin{array}{l}\text { WB } 8(\%) \\
(\text { CLC } 4 * * \\
\text { and } 5 * *)\end{array}$ & & \\
\hline 1 & $\begin{array}{l}\text { FH01_01 } \\
\text { FH01_02 }\end{array}$ & $\begin{array}{l}1 \\
2\end{array}$ & 27.12.1968 & Winter & $\begin{array}{l}\text { Mediterranean } \\
\text { Mediterranean }\end{array}$ & Riverine & $\begin{array}{l}26.12 .1968 \\
26.12 .1968\end{array}$ & $\begin{array}{l}154.30 \\
199.50\end{array}$ & $\begin{array}{l}\mathrm{NZ} \\
\mathrm{NZ}\end{array}$ & $\begin{array}{c}56.99 \\
100\end{array}$ & $\begin{array}{l}5.43 \\
4.71\end{array}$ & $\begin{array}{c}15.90 \\
6.58\end{array}$ & $\begin{array}{l}0.7 \\
1.6\end{array}$ & $\begin{array}{l}1.2 \\
0.0\end{array}$ & $\begin{array}{c}15,024.10 \\
458.10\end{array}$ & $\begin{array}{l}5 \\
5\end{array}$ \\
\hline \multirow{3}{*}{2} & FH02_01 & 3 & \multirow{3}{*}{30.03 .1980} & \multirow{3}{*}{ Spring } & Central Anatolia & \multirow{3}{*}{ Flash } & 27.03 .1980 & 45.20 & SEZ & 0 & 8.01 & 2.76 & 0.8 & 0.0 & 126.00 & 3 \\
\hline & FH02__02 & 4 & & & Central Anatolia & & 27.03.1980 & 48.50 & SEZ & 0 & 7.10 & 13.54 & 6.7 & 0.2 & 1561.20 & 3 \\
\hline & FH02_03 & 5 & & & Central Anatolia & & 27.03.1980 & 80.60 & SEZ & 0 & 4.07 & 2.54 & 1.2 & 0.0 & 150.40 & 6 \\
\hline & FH03_01 & 6 & & & Aegean & & 04.11 .1995 & 108.00 & $\mathrm{NZ}$ & 0 & 5.22 & 0.01 & 25.9 & 0.0 & 34.50 & 6 \\
\hline & FH03_02 & 7 & & & Mediterranean & & 04.11.1995 & 210.00 & NZ & 0 & 6.01 & 7.49 & 92.5 & 0.0 & 8.70 & 2 \\
\hline 3 & FH03_03 & 8 & 04.11.1995 & Autumn & Mediterranean & Flash & 04.11.1995 & 210.00 & NZ & 0 & 4.31 & 14.98 & 81.2 & 0.0 & 5.20 & 2 \\
\hline & FH04_01 & 10 & & & Black Sea & & 08.08 .1998 & 45.50 & WA & 0 & 4.76 & 0.00 & 0.3 & 0.0 & 231.40 & 6 \\
\hline 4 & FH04_02 & 11 & 10.08.1998 & Summer & Black Sea & Flash & 08.08.1998 & 45.50 & WA & 0 & 4.14 & 0.72 & 0.4 & 0.1 & 1063.80 & 6 \\
\hline & FH04_03 & 12 & & & Black Sea & & 08.08.1998 & 45.50 & WA & 0 & 4.33 & 0.00 & 0.1 & 0.3 & 1064.50 & 6 \\
\hline & FH05_01 & 13 & & & Black Sea & & 20.06 .1990 & 64.80 & SWZ & 100 & 4.14 & 0.72 & 0.4 & 0.1 & 1063.80 & 5 \\
\hline & FH05_02 & 14 & & & Black Sea & & 19.06.1990 & 43.00 & SWZ & 0 & 4.74 & 0.73 & 0.6 & 0.0 & 19.50 & 6 \\
\hline & FH05_03 & 15 & & & Black Sea & & 19.06.1990 & 58.30 & SWZ & 8.2 & 4.19 & 0.26 & 0.3 & 0.3 & 3155.60 & 6 \\
\hline 5 & FH05_04 & 16 & 18.06.1990 & Summer & Black Sea & Flash & 19.06.1990 & 43.00 & sWZ & 93.4 & 4.51 & 0.00 & 0.2 & 0.0 & 113.40 & 5 \\
\hline & FH05_05 & 17 & & & Black Sea & & 19.06.1990 & 58.30 & SWZ & 0 & 4.65 & 0.00 & 0.0 & 0.1 & 535.30 & 6 \\
\hline & FH05_06 & 18 & & & Black Sea & & 19.06.1990 & 58.30 & SWZ & 0 & 4.58 & 0.00 & 0.4 & 0.3 & 801.00 & 6 \\
\hline & FH05_07 & 19 & & & Black Sea & & 19.06 .1990 & 58.30 & sWZ & 0 & 5.02 & 0.00 & 0.5 & 0.0 & 105.70 & 6 \\
\hline & FH06_01 & 20 & & & Southeastern Anatolia & & 27.10 .2006 & 35.90 & SWZ & 0 & 4.24 & 16.57 & 10.8 & 0.0 & 111.00 & 6 \\
\hline & FH06_03 & 21 & & & Southeastern Anatolia & & 28.10.2006 & 64.00 & $\mathrm{BM}$ & 0 & 5.71 & 75.32 & 24.0 & 0.0 & 8.20 & 4 \\
\hline 6 & FH06_06 & 23 & 27.10.2006 & Autumn & Southeastern Anatolia & Flash & 28.10 .2006 & 52.00 & BM & 0 & 5.80 & 51.88 & 0.9 & 0.2 & 1736.90 & 6 \\
\hline & FH06_07 & 24 & & & Southeastern Anatolia & & 29.10.2006 & 51.00 & BM & 34.1 & 5.99 & 33.35 & 2.5 & 0.7 & 4150.20 & 6 \\
\hline & FH06_08 & 25 & & & Southeastern Anatolia & & 29.10 .2006 & 29.80 & BM & 0 & 2.54 & 0.00 & 0.0 & 0.0 & 18.80 & 6 \\
\hline & FH06_10 & 26 & & & Southeastern Anatolia & & 29.10.2006 & 37.60 & BM & 79.7 & 6.68 & 36.71 & 5.4 & 0.0 & 310.70 & 5 \\
\hline & FH07_01 & 27 & & & Eastern Anatolia & & 16.05 .1991 & 28.70 & TRM & 0 & 5.54 & 22.82 & 1.6 & 2.9 & 6232.00 & 6 \\
\hline 7 & FH07_02 & 28 & 16.05 .1991 & Spring & Eastern Anatolia & Flash & 16.05 .1991 & 18.20 & TRM & 0 & 6.15 & 0.00 & 0.0 & 0.0 & 18.40 & 6 \\
\hline & FH07_03 & 29 & & & Eastern Anatolia & & 16.05 .1991 & 28.20 & TRM & 0 & 4.43 & 2.18 & 0.0 & 4.2 & 282.30 & 6 \\
\hline & FH08 01 & 30 & & & Marmara & & 09.09 .2009 & 248.00 & BM & 0 & 5.63 & 19.26 & 20.8 & 3.1 & 163.90 & 4 \\
\hline 8 & FH0__02 & 31 & 07.09.2009 & Autumn & Marmara & Flash & 09.09 .2009 & 248.00 & BM & 0 & 3.61 & 73.47 & $\begin{array}{l}2.0 \\
13.1\end{array}$ & $\begin{array}{l}.1 \\
0.0\end{array}$ & 37.20 & 4 \\
\hline & FH09_01 & 32 & & & Black Sea & & 23.07 .2002 & 154.80 & WZ & 0 & 4.98 & 1.80 & 0.0 & 2.4 & 329.20 & 6 \\
\hline & FH09_02 & 33 & & & Black Sea & & 23.07 .2002 & 154.80 & WZ & 0 & 4.44 & 0.00 & 0.2 & 1.1 & 205.70 & 6 \\
\hline & FH09_03 & 34 & 20070 & $s_{-}$ & Central Anatolia & & 23.07.2002 & 64.30 & WZ & 0 & 5.03 & 65.72 & 1.3 & 0.0 & 844.50 & 6 \\
\hline 9 & FH09_04 & 35 & 23.07 .2002 & Summer & Central Anatolia & Flash & 23.07 .2002 & 64.30 & wZ & 0 & 3.11 & 17.33 & 2.1 & 0.1 & 633.70 & 6 \\
\hline & FH09_05 & 36 & & & Eastern Anatolia & & 24.07.2002 & 22.80 & WZ & 0 & 6.10 & 6.00 & 2.1 & 0.3 & 2334.70 & 6 \\
\hline & FH09_06 & 37 & & & Eastern Anatolia & & 24.07 .2002 & 12.50 & WZ & 0 & 5.63 & 9.19 & 1.4 & 2.3 & 2267.10 & 6 \\
\hline 10 & FH10_01 & 38 & 19.11.1974 & Autumn & Southeastern Anatolia & NA & 19.11.1974 & 40.70 & SWZ & 0 & 5.89 & 1.41 & 1.0 & 7.5 & $57,593.40$ & 1 \\
\hline
\end{tabular}


Table A1. Cont.

\begin{tabular}{|c|c|c|c|c|c|c|c|c|c|c|c|c|c|c|c|c|}
\hline \multirow[b]{2}{*}{$\begin{array}{l}\text { Event } \\
\text { Number }\end{array}$} & \multirow[b]{2}{*}{ Case ID } & \multirow[b]{2}{*}{$\begin{array}{l}\text { Case } \\
\text { Number }\end{array}$} & \multicolumn{4}{|c|}{ General Information } & \multirow[b]{2}{*}{$\begin{array}{l}\text { Corrected Event } \\
\text { Date } \\
\text { (Day-Month-Year) }\end{array}$} & \multirow[b]{2}{*}{$\begin{array}{l}\text { PREC }^{1} \\
\text { (mm/day) }\end{array}$} & \multirow[b]{2}{*}{$\mathrm{ACP}^{2}$} & \multirow[b]{2}{*}{$\underset{(\%)}{\text { ASM }^{3}}$} & \multirow[b]{2}{*}{$\begin{array}{c}\mathrm{IN}^{4} \\
\left(\mathrm{~km} / \mathrm{km}^{2}\right)\end{array}$} & \multirow[b]{2}{*}{$\operatorname{IR}^{5}(\%)$} & \multicolumn{2}{|c|}{ Land Use Information } & \multirow[b]{2}{*}{$\begin{array}{l}\text { TCA } \\
\left(\mathbf{k m}^{2}\right)\end{array}$} & \multirow[b]{2}{*}{$\begin{array}{l}\text { Cluste } \\
\text { No. }\end{array}$} \\
\hline & & & $\begin{array}{c}\text { Event Date } \\
\text { (Day-Month-Year) }\end{array}$ & $\begin{array}{l}\text { Event } \\
\text { Season }\end{array}$ & Geographic Region & $\begin{array}{l}\text { Flood } \\
\text { Type }\end{array}$ & & & & & & & $\begin{array}{l}\mathrm{UA}^{6}(\%) \\
\left(\operatorname{CLC}^{7} 1^{* *}\right)\end{array}$ & $\begin{array}{l}\text { WB }{ }^{8}(\%) \\
\left(\text { CLC } 4^{* * *}\right. \\
\text { and } 5 * *)\end{array}$ & & \\
\hline \multirow{6}{*}{11} & FH11_01 & 39 & \multirow{6}{*}{12.06 .1998} & \multirow{6}{*}{ Summer } & Southeastern Anatolia & \multirow{6}{*}{ Flash } & 13.06.1998 & 26.80 & TRM & 0 & 5.54 & 22.93 & 1.6 & 2.9 & 6232.00 & 6 \\
\hline & FH11_02 & 40 & & & Southeastern Anatolia & & 12.06.1998 & 0.60 & TRM & 0 & 4.24 & 16.57 & 10.8 & 0.0 & 111.00 & 6 \\
\hline & FH11_03 & 41 & & & Eastern Anatolia & & 12.06.1998 & 21.50 & TRM & 0 & 5.36 & 6.54 & 0.9 & 3.7 & 519.70 & 6 \\
\hline & FH11_04 & 42 & & & Eastern Anatolia & & 12.06 .1998 & 8.80 & TRM & 0 & 5.12 & 1.85 & 4.1 & 0.0 & 165.80 & 6 \\
\hline & FH11_05 & 43 & & & Eastern Anatolia & & 13.06.1998 & 12.62 & TRM & 0 & 5.86 & 2.35 & 1.0 & 4.0 & 2195.70 & 6 \\
\hline & FH11_06 & 44 & & & Eastern Anatolia & & 13.06.1998 & 7.48 & TRM & 0 & 9.33 & 0.00 & 21.4 & 0.0 & 14.80 & 3 \\
\hline \multirow{3}{*}{12} & FH12_01 & 45 & \multirow{3}{*}{18.02 .1990} & \multirow{3}{*}{ Winter } & Eastern Anatolia & & 18.02 .1990 & 44.50 & SWA & 100 & 7.96 & 40.40 & 1.5 & 0.0 & 10.70 & 5 \\
\hline & FH12_02 & 46 & & & Eastern Anatolia & Flash & 18.02 .1990 & 72.90 & SWA & 100 & 4.30 & 0.35 & 0.1 & 0.0 & 108.60 & 5 \\
\hline & FH12_03 & 47 & & & Southeastern Anatolia & & 14.02 .1990 & 37.20 & SWA & 0 & 5.57 & 24.12 & 23.0 & 0.3 & 124.80 & 6 \\
\hline & FH13_01 & 48 & & & Eastern Anatolia & & 05.03 .2004 & 14.20 & BM & 0 & 9.33 & 0.00 & 21.4 & 0.0 & 14.80 & 3 \\
\hline & FH13_02 & 49 & & & Southeastern Anatolia & & 06.03 .2004 & 8.20 & BM & 0 & 6.68 & 36.71 & 5.4 & 0.0 & 310.70 & 6 \\
\hline & FH13_03 & 50 & 05,032004 & Spring & Eastern Anatolia & & 06.03 .2004 & 62.80 & BM & 0 & 4.70 & 0.00 & 0.5 & 0.0 & 47.30 & 6 \\
\hline 13 & FH13_04 & 51 & 05.03 .2004 & Spring & Eastern Anatolia & Kiverine & 06.03 .2004 & 54.70 & BM & 0 & 5.80 & 9.32 & 1.4 & 2.3 & 2234.40 & 6 \\
\hline & FH13_05 & 52 & & & Central Anatolia & & 05.03 .2004 & 18.20 & BM & 0 & 5.42 & 4.96 & 0.6 & 0.5 & 623.60 & 6 \\
\hline & FH13_06 & 53 & & & Mediterranean & & 05.03 .2004 & 26.20 & BM & 0 & 5.41 & 3.28 & 0.3 & 0.6 & $10,731.60$ & 6 \\
\hline 14 & FH14_01 & 54 & 13.06.1988 & Summer & Central Anatolia & Flash & 12.06.1988 & 71.30 & $\mathrm{HB}$ & 0 & 6.25 & 12.52 & 7.4 & 0.2 & 1082.70 & 3 \\
\hline & FH15_01 & 55 & & & Eastern Anatolia & & 27.05 .2007 & 8.60 & TRW & 0 & 5.40 & 6.58 & 0.6 & 3.7 & 516.70 & 6 \\
\hline & FH15_02 & 56 & & Spring & Eastern Anatolia & & 27.05.2007 & 3.30 & TRW & 0 & 5.49 & 0.64 & 3.4 & 4.8 & 163.80 & 6 \\
\hline 15 & FH15_03 & 57 & 27.05 .2007 & spring & Eastern Anatolia & Flash & 27.05.2007 & 1.20 & TRW & 0 & 4.70 & 0.00 & 0.5 & 0.0 & 47.30 & 6 \\
\hline & FH15_04 & 58 & & & Southeastern Anatolia & & 27.05 .2007 & 5.60 & TRW & 0 & 5.57 & 24.12 & 23.0 & 0.3 & 124.80 & 6 \\
\hline 16 & FH16_01 & 59 & 03.07 .2012 & Summer & Black Sea & Riverine & 04.07 .2012 & 68.40 & TRW & 100 & 4.50 & 2.77 & 1.4 & 0.1 & 817.50 & 5 \\
\hline & FH17_01 & 60 & & & Eastern Anatolia & & 03.07 .2006 & 8.30 & SEA & 0 & 4.70 & 0.00 & 0.5 & 0.0 & 47.30 & 6 \\
\hline & FH17_02 & 61 & & & Eastern Anatolia & & 04.07 .2006 & 12.50 & SEA & 0 & 5.80 & 9.32 & 1.4 & 2.3 & 2234.40 & 6 \\
\hline & FH17_03 & 62 & & & Marmara & & 03.07 .2006 & 74.90 & SEA & 0 & 2.72 & 85.14 & 14.4 & 0.0 & 7.90 & 4 \\
\hline 17 & FH17_04 & 63 & 01.07 .2006 & Summer & Black Sea & $\mathrm{NA}$ & 06.07 .2006 & 26.30 & TRW & 0 & 4.50 & 10.64 & 4.6 & 3.2 & 179.60 & 6 \\
\hline & FH17_05 & 64 & & & Black Sea & & 02.07 .2006 & 95.20 & SEA & 0 & 4.98 & 1.80 & 0.0 & 2.4 & 329.20 & 6 \\
\hline & FH17_06 & 65 & & & Black Sea & & 02.07 .2006 & 9.20 & SEA & 0 & 4.15 & 3.43 & 1.2 & 0.0 & 331.70 & 6 \\
\hline & FH17_07 & 66 & & & Black Sea & & 02.07 .2006 & 77.30 & SEA & 0 & 4.46 & 0.52 & 0.3 & 0.0 & 166.70 & 6 \\
\hline 18 & FH18_01 & 67 & 17.12.1981 & Winter & Black Sea & $\mathrm{NA}$ & 16.12.1981 & 18.30 & WS & 0 & 4.15 & 3.43 & 1.2 & 0.0 & 331.70 & 6 \\
\hline & FH19_01 & 68 & & & Black Sea & & 20.05 .1998 & 73.00 & NWZ & 32.4 & 5.39 & 0.00 & 1.2 & 0.4 & $13,315.60$ & 6 \\
\hline 19 & FH19_03 & 69 & 20.05.1998 & Spring & Black Sea & Flash & 21.05 .1998 & 93.20 & NWZ & 100 & 5.43 & 3.54 & 1.3 & 0.9 & 652.70 & 5 \\
\hline & FH19_04 & 70 & & & Black Sea & & 20.05.1998 & 59.90 & NWZ & 0 & 5.41 & 5.57 & 3.3 & 0.6 & 913.70 & 6 \\
\hline 20 & FH20_01 & 71 & 20.06 .2002 & Summer & Black Sea & Flash & 20.06 .2002 & 57.80 & SWA & 0 & 4.46 & 0.52 & 0.3 & 0.0 & 166.70 & 6 \\
\hline 21 & FH21_01 & 72 & 13.07.1995 & Summer & Mediterranean & NA & 14.07.1995 & 28.20 & HNFA & 0 & 4.96 & 0.00 & 1.0 & 0.3 & 306.10 & 6 \\
\hline 22 & FH22_01 & 73 & 15.12 .1997 & Winter & Mediterranean & Flash & 15.12 .1997 & 31.90 & SEZ & 24.5 & 4.50 & 69.92 & 29.8 & 0.0 & 65.30 & 4 \\
\hline 23 & FH23_01 & 74 & 20.07 .2009 & Summer & Black Sea & Flash & 21.07 .2009 & 132.20 & SWZ & 0 & 4.46 & 0.52 & 0.3 & 0.0 & 166.70 & 6 \\
\hline & FH24_01 & 75 & & & Black Sea & & 27.05 .2000 & 79.00 & WZ & 0.2 & 5.66 & 1.80 & 1.0 & 0.7 & $36,115.80$ & 1 \\
\hline 24 & FH24_03 & 76 & 27.05 .2000 & Spring & Black Sea & NA & 27.05.2000 & 40.70 & $\mathrm{WZ}$ & 0 & 5.26 & 6.14 & 0.9 & 0.5 & 546.10 & 6 \\
\hline & FH24_04 & 77 & & & Black Sea & & 26.05 .2000 & 17.60 & WZ & 0 & 4.79 & 0.11 & 7.1 & 0.0 & 64.40 & 6 \\
\hline 25 & FH25_01 & 78 & 24.12 .2003 & Winter & Mediterranean & NA & 24.12 .2003 & 105.40 & BM & 0 & 5.55 & 16.10 & 1.4 & 0.2 & 3847.00 & 6 \\
\hline
\end{tabular}

${ }^{1}$ PREC, Corrected Event Day Precipitation; ${ }^{2}$ ACP, Atmospheric Circulation Pattern Type; ${ }^{3}$ ASM, Antecedent Soil Moisture; ${ }^{4}$ IN, Infiltration Number; ${ }^{5}$ IR, Infiltration Rate; ${ }^{6}$ UA, Urbanized Areas; ${ }^{7}$ CLC, Corine Land Cover; ${ }^{8}$ WB, Water Bodies; ${ }^{9}$ TCA, Total Catchment Area. 


\begin{tabular}{|c|c|c|c|}
\hline Number & Province Name & Number & Province Name \\
\hline 1 & ADANA & 21 & ISPARTA \\
\hline 2 & ADAPAZARI (SAKARYA) & 22 & ISTANBUL \\
\hline 3 & ADIYAMAN & 23 & IZMIR \\
\hline 4 & AGRI & 24 & KARABÜK \\
\hline 5 & AMASYA & 25 & KARS \\
\hline 6 & ANKARA & 26 & KAYSERI \\
\hline 7 & ANTALYA & 27 & KONYA \\
\hline 8 & ARDAHAN & 28 & MALATYA \\
\hline 9 & BARTIN & 29 & MERSIN \\
\hline 10 & BATMAN & 30 & MUS \\
\hline 11 & BINGOL & 31 & RIZE \\
\hline 12 & BITLIS & 32 & SAMSUN \\
\hline 13 & CORUM & 33 & SANLIURFA \\
\hline 14 & DIYARBAKIR & 34 & SIRNAK \\
\hline 15 & ELAZIG & 35 & TEKIRDAG \\
\hline 16 & ERZINCAN & 36 & TOKAT \\
\hline 17 & ERZURUM & 37 & TRABZON \\
\hline 18 & GAZIANTEP & 38 & VAN \\
\hline 19 & GIRESUN & 39 & YOZGAT \\
\hline 20 & GÜMÜSHANE & 40 & ZONGULDAK \\
\hline
\end{tabular}

Figure A1. Province names numbered in Figure 2.

Table A2. Hydrologic soil groups according to their major soil group classification [50].

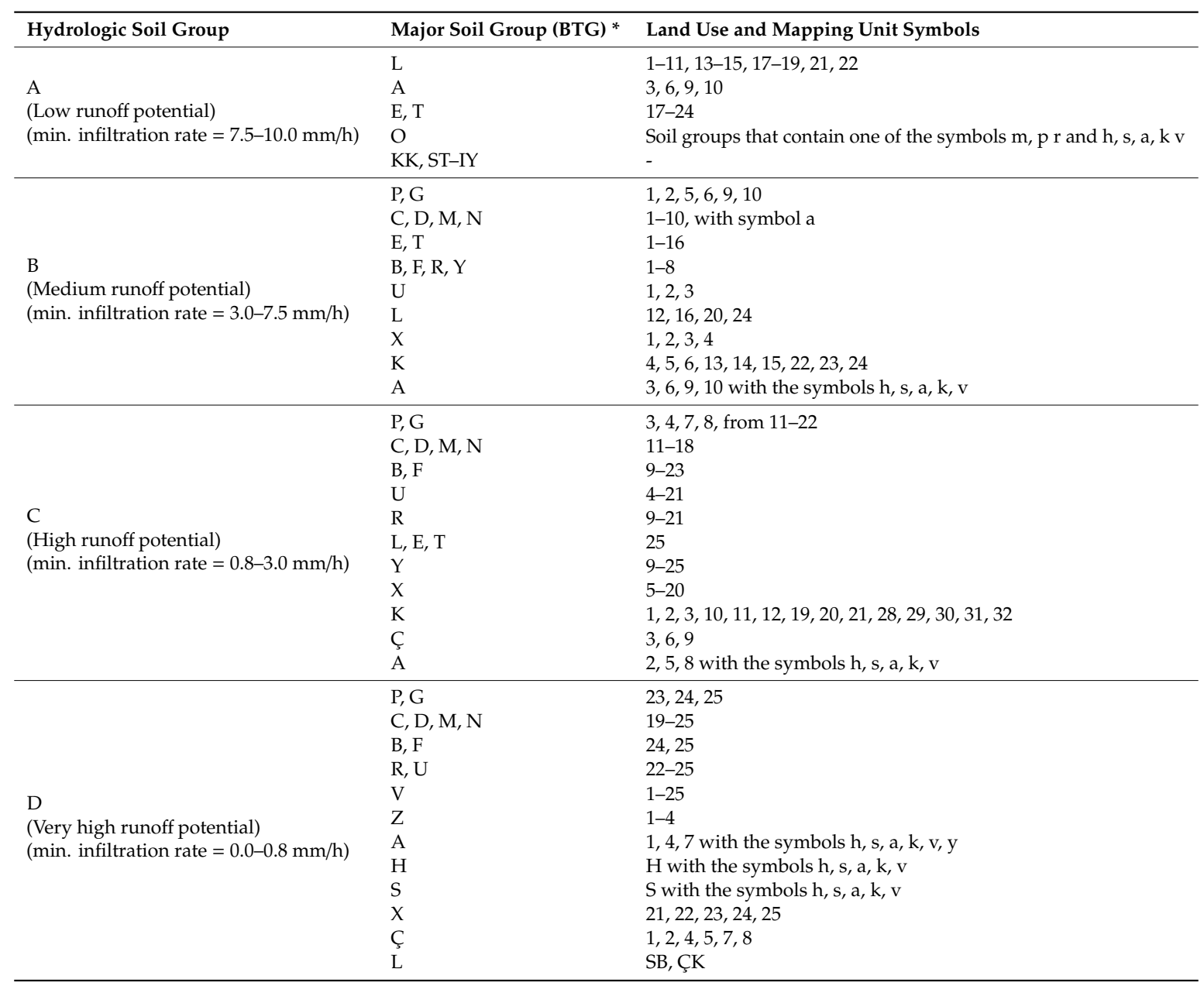

* Please see the Appendix A, Table A3 for the major soil group symbols. 
Table A3. Mapping units of major soil groups in Turkey [90].

\begin{tabular}{|c|c|c|c|c|c|c|c|c|c|}
\hline Symbol & Major Soil Groups & Symbol & Major Soil Groups & Symbol & Soil Type & Symbol & Slope-Depth Combination & Symbol & Slope-Depth Combination \\
\hline $\mathrm{P}$ & Red Yellow Podzol Soils & $x$ & Basaltic Soils & $\mathrm{h}$ & Brackish & 1 & Very deep $(90+\mathrm{m}) /$ Slope $\% 0-2$ & 16 & $\begin{array}{l}\text { Very shallow }(20-0 \mathrm{~m}) / \text { Slope } \\
\% 12-20\end{array}$ \\
\hline G & Grey Brown Podzol Soils & $\mathrm{Y}$ & Upland Soils & $\mathrm{s}$ & Saline & 2 & Deep $(90-50 \mathrm{~m}) /$ Slope $\% 0-2$ & 17 & Very deep $(90+\mathrm{m}) /$ Slope $\% 20-30$ \\
\hline $\mathrm{M}$ & Brown Forest Soils & A & Alluvial Soils & $\mathrm{a}$ & Alkali & 3 & Shallow $(50-20 \mathrm{~m}) /$ Slope $\% 0-2$ & 18 & Deep (90-50 m)/Slope \%20-30 \\
\hline $\mathrm{N}$ & Non-Calcareous Brown Forest Soils & $\mathrm{H}$ & Gleysol & $\mathrm{k}$ & Brackish-Alkali & 4 & Very shallow $(20-0 \mathrm{~m}) /$ Slope $\% 0-2$ & 19 & Shallow $(50-20 \mathrm{~m}$ )/Slope $\% 20-30$ \\
\hline $\mathrm{CE}$ & Chestnut Soil & $\mathrm{s}$ & $\begin{array}{l}\text { Alluvial Coastal } \\
\text { Soils }\end{array}$ & $\mathrm{v}$ & Saline-Alkali & 5 & Very deep $(90+\mathrm{m}) /$ Slope $\% 2-6$ & 20 & $\begin{array}{l}\text { Very shallow }(20-0 \mathrm{~m}) / \text { Slope } \\
\% 20-30\end{array}$ \\
\hline $\mathrm{D}$ & Reddish Chestnut Soil & $\mathrm{K}$ & Colluvial Soils & $\mathrm{t}$ & Stony & 6 & Deep (90-50 m)/Slope \%2-6 & 21 & Very deep $(90+\mathrm{m}) /$ Slope $\% 30+$ \\
\hline $\mathrm{T}$ & Red Mediterranean Soils & $\mathrm{C}$ & Saline-Alkali Soil & $\mathrm{r}$ & Rocky & 7 & Shallow $(50-20 \mathrm{~m}) /$ Slope $\% 2-6$ & 22 & Deep (90-50 m)/Slope \%30+ \\
\hline $\mathrm{E}$ & Red Brown Mediterranean Soils & $\mathrm{O}$ & Organic Soils & $\mathrm{y}$ & Poor drainage & 8 & Very shallow $(20-0 \mathrm{~m}) /$ Slope $\% 2-6$ & 23 & Shallow $(50-20 \mathrm{~m}) /$ Slope $\% 30+$ \\
\hline B & Brown Soils & & & $\mathrm{f}$ & Very poor drainage & 9 & Very deep $(90+\mathrm{m}) /$ Slope $\% 6-12$ & 24 & Very shallow $(20-0 \mathrm{~m}) /$ Slope $\% 30+$ \\
\hline $\mathrm{U}$ & Non-Calcareous Brown Soils & & & CK & $\begin{array}{l}\text { Bare rocks and } \\
\text { boulders }\end{array}$ & 10 & Deep (90-50 m)/Slope \%6-12 & 25 & Lithosolic \\
\hline $\mathrm{F}$ & Reddish Brown Soils & & & IY & River flood plains & 11 & Shallow $(50-20 \mathrm{~m}$ )/Slope $\% 6-12$ & 26 & Lithosolic \\
\hline $\mathrm{R}$ & Rendzina & & & SK & Coastal Sand Dunes & 12 & $\begin{array}{l}\text { Very shallow }(20-0 \mathrm{~m}) / \text { Slope } \\
\% 6-12\end{array}$ & 27 & Lithosolic \\
\hline $\mathrm{V}$ & Vertisol Soil & & & KK & Ground Sand Dunes & 13 & Very deep $(90+\mathrm{m}) /$ Slope $\% 12-20$ & 28 & Lithosolic \\
\hline $\mathrm{Z}$ & Sierozem & & & SB & Marshes & 14 & Deep $(90-50 \mathrm{~m}$ )/Slope \%12-20 & 29 & Lithosolic \\
\hline $\mathrm{L}$ & Regosol & & & DK & $\begin{array}{l}\text { Permanent } \\
\text { snow-cover }\end{array}$ & 15 & Shallow $(50-20 \mathrm{~m}$ )/Slope $\% 12-20$ & 30 & Lithosolic \\
\hline
\end{tabular}


Complete Linkage Method (No ACP)

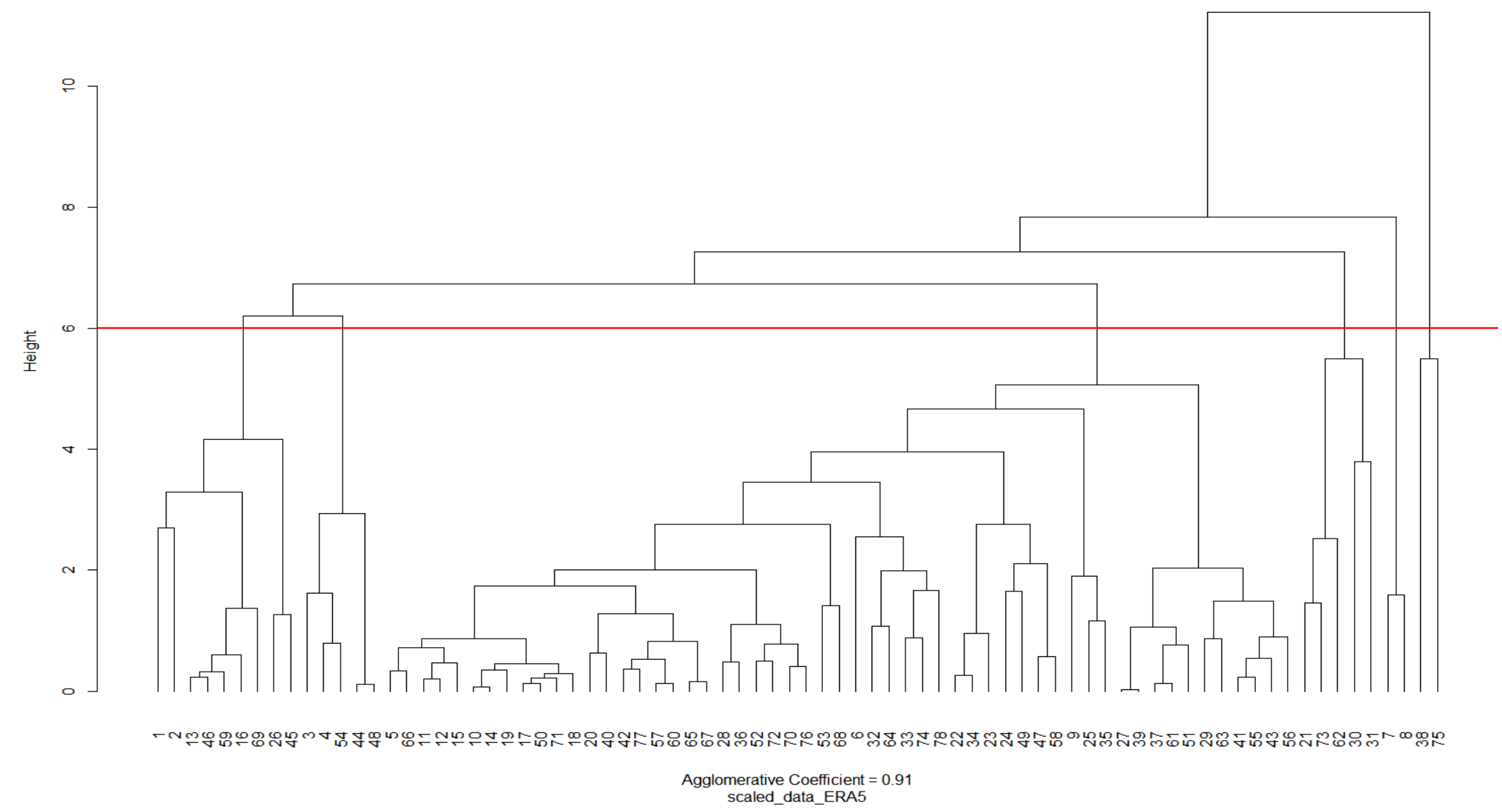

Figure A2. Dendrogram of the cluster analysis. 


\section{References}

1. Koç, G.; Thieken, A.H. The relevance of flood hazards and impacts in Turkey: What can be learned from different disaster loss databases? Nat. Hazards 2018, 91, 375-408. [CrossRef]

2. Kadığlu, M. Türkiye'de iklim degisikligi risk yonetimi (Climate change risk management in Turkey). In Turkiye'nin Iklim Degisikligi II. Ulusal Bildiriminin Hazirlanmasi Projesi Yayini; T.C. Çevre ve Şehircilik Bakanlığ1: Ankara, Turkey, 2012; p. 172. Available online: http://www.undp.org/content/dam/turkey/docs/ projectdocuments/EnvSust/UNDP-TR-Iklim_Degisikligi_Risk_Yonetimi.pdf (accessed on 29 May 2020).

3. Nied, M.; Pardowitz, T.; Nissen, K.; Ulbrich, U.; Hundecha, Y.; Merz, B. On the relationship between hydro-meteorological patterns and flood types. J. Hydrol. 2014, 519, 3249-3262. [CrossRef]

4. Turkington, T.; Breinl, K.; Ettema, J.; Alkema, D.; Jetten, V. A new flood type classification method for use in climate change impact studies. Weather Clim. Extrem. 2016, 14, 1-16. [CrossRef]

5. Prudhomme, C.; Crooks, S.; Kay, A.L.; Reynard, N. Climate change and river flooding: Part 1 classifying the sensitivity of British catchments. Clim. Chang. 2013, 119, 933-948. [CrossRef]

6. Schröter, K.; Kunz, M.; Elmer, F.; Mühr, B.; Merz, B. What made the June 2013 flood in Germany an exceptional event? A hydro-meteorological evaluation. Hydrol. Earth Syst. Sci. 2015, 19, 309-327. [CrossRef]

7. Merz, R.; Blöschl, G. A Process Typology of Regional Floods. Water Resour. Res. 2003, 39. [CrossRef]

8. Beurton, S.; Thieken, A.H. Seasonality of Floods in Germany. Hydrol. Sci. J. 2009, 54, 62-76. [CrossRef]

9. Baltaci, H.; Göktürk, O.M.; Kindap, T.; Ünal, A.; Karaca, M. Atmospheric circulation types in Marmara Region (NW Turkey) and their influence on precipitation. Int. J. Climatol. 2015, 35, 1810-1820. [CrossRef]

10. Baltaci, H. Meteorological analysis of flash floods in Artvin (NE Turkey) on August 24, 2015. Nat. Hazards Earth Syst. Sci. Discuss. 2017, 1-23. [CrossRef]

11. Kömüşcü, A.Ü.; Çelik, S. Analysis of the Marmara flood in Turkey, 7-10 September 2009: An assessment from hydrometeorological perspective. Nat. Hazards 2013, 66, 781-808. [CrossRef]

12. Türkeş, M.; Tatli, H. Use of the spectral clustering to determine coherent precipitation regions in Turkey for the period 1929-2007. Int. J. Clim. 2010, 31, 2055-2067. [CrossRef]

13. Lolis, C.J.; Türkeş, M. Atmospheric circulation characteristics favouring extreme precipitation in Turkey. Clim. Res. 2016, 71, 139-153. [CrossRef]

14. Sariş, F.; Hannah, D.M.; Eastwood, W.J. Spatial variability of precipitation regimes over Turkey. Hydrol. Sci. J. 2010, 55, 234-249. [CrossRef]

15. Merz, B.; Apel, H.; Dung, N.V.; Falter, D.; Hundecha, Y.; Kreibich, H.; Schröter, K.; Vorogushyn, S. Large-scale flood risk assessment using a coupled model chain. In Proceedings of the E3S Web of Conferences, Swieradow-Zdroj, Poland, 25-28 September 2016; EDP Sciences: Les Ulis, France, 2016; Volume 7, p. 11005. [CrossRef]

16. Thieken, A.H.; Apel, H.; Merz, B. Assessing the probability of large-scale flood loss events: A case study for the river Rhine, Germany. J. Flood Risk Manag. 2014, 8, 247-262. [CrossRef]

17. Sivapalan, M. Process complexity at hillslope scale, process simplicity at the watershed scale: Is there a connection? Hydrol. Process. 2003, 17, 1037-1041. [CrossRef]

18. Merz, B.; Aerts, J.; Arnbjerg-Nielsen, K.; Baldi, M.; Becker, A.; Bichet, A.; Bloschl, G.; Bouwer, L.M.; Brauer, A.; Cioffi, F.; et al. Floods and climate: Emerging perspectives for flood risk assessment and management. Nat. Hazards Earth Syst. Sci. 2014, 14, 1921-1942. [CrossRef]

19. Zscheischler, J.; Westra, S.; Hurk, B.V.D.; Seneviratne, S.I.; Ward, P.J.; Pitman, A.; AghaKouchak, A.; Bresch, D.N.; Leonard, M.; Wahl, T.; et al. Future climate risk from compound events. Nat. Clim. Chang. 2018, 8, 469-477. [CrossRef]

20. Hammer, C.L.; Kostroch, D.C.; Quirós, G.S.T.A. Internal Group. What challenges come with big data? In Big Data: Potential, Challenges and Statistical Implications, 1st ed.; International Monetary Fund: Washington, DC, USA, 2017; pp. 20-23, ISBN 9781484310908.

21. Kandilioti, G.; Makropoulos, C. Preliminary flood risk assessment: The case of Athens. Nat. Hazards 2011, 61, 441-468. [CrossRef]

22. Sayers, P.B.; Hall, J.W.; Meadowcroft, I.C. Towards risk-based flood hazard management in the UK. Proc. Inst. Civ. Eng. Civ. Eng. 2002, 150, 36-42. [CrossRef] 
23. Tarasova, L.; Merz, R.; Kiss, A.; Basso, S.; Blöschl, G.; Merz, B.; Viglione, A.; Plötner, S.; Guse, B.; Schumann, A.; et al. Causative classification of river flood events. Wiley Interdiscip. Rev. Water 2019, 6, e1353. [CrossRef]

24. Meteoroloji Genel Müdürlügü (Turkish State Meteorological Service). Available online: https://www.mgm. gov.tr/ (accessed on 15 May 2020).

25. Meteoroloji Genel Müdürlügü, Meteoroloji Tarihi (History of Meteorology). Available online: https: //mgm.gov.tr/genel/meteorolojitarihi.aspx (accessed on 26 September 2019).

26. Meteoroloji Genel Müdürlügü, About TSMS. Available online: https://www.mgm.gov.tr/eng/about.aspx. (accessed on 6 May 2019).

27. Meteoroloji Genel Müdürlügü, Meteorological Data Information Sales and Presentation System (MEVBIS). Available online: https://mevbis.mgm.gov.tr/mevbis/ui/index.html\#/Workspace (accessed on 6 May 2019).

28. Meteoroloji Genel Müdürlügü, İstasyon Bilgileri Veritabanı (Station Database Information). Available online: https://www.mgm.gov.tr/kurumsal/istasyonlarimiz.aspx?sSirala=LT\&m=ZONGULDAK\#sfB (accessed on 7 May 2019).

29. ECMWF-European Centre for Medium-Range Weather Forecasts ERA5. Available online: https://cds.climate. copernicus.eu/cdsapp\#!/dataset/reanalysis-era5-single-levels?tab=overview (accessed on 4 October 2019).

30. Bárdossy, A.; Filiz, F. Identification of flood producing atmospheric circulation patterns. J. Hydrol. 2005, 313, 48-57. [CrossRef]

31. Huth, R.; Beck, C.; Philipp, A.; Demuzere, M.; Ustrnul, Z.; Cahynová, M.; Kyselý, J.; Tveito, O.E. Classifications of Atmospheric Circulation Patterns. Ann. New York Acad. Sci. 2008, 1146, 105-152. [CrossRef] [PubMed]

32. Bárdossy, A. Atmospheric circulation pattern classification for South-West Germany using hydrological variables. Phys. Chem. Earth, Parts A/B/C 2010, 35, 498-506. [CrossRef]

33. Littmann, T. An empirical classification of weather types in the Mediterranean Basin and their interrelation with rainfall. Theor. Appl. Clim. 2000, 66, 161-171. [CrossRef]

34. James, P.M. An objective classification method for Hess and Brezowsky Grosswetterlagen over Europe. Theor. Appl. Clim. 2006, 88, 17-42. [CrossRef]

35. Schwander, M.; Brönnimann, S.; Delaygue, G.; Rohrer, M.; Auchmann, R.; Brugnara, Y. Reconstruction of Central European daily weather types back to 1763. Int. J. Clim. 2017, 37, 30-44. [CrossRef]

36. Kučerová, M.; Beck, C.; Philipp, A.; Huth, R. Trends in frequency and persistence of atmospheric circulation types over Europe derived from a multitude of classifications. Int. J. Clim. 2016, 37, 2502-2521. [CrossRef]

37. Baur, F.; Hess, P.; Nagel, H. Kalender der Grosswetterlagen Europas 1881-1939; Forschungsinstitut für langfristige Witterungsvorhersage: Bad Homburg, Germany, 1944; 35 p.

38. Hess, P.; Brezowsky, H. Katalog der Grosswetterlagen Mitteleuropas. Berichte des Dtsch. Wetterdienstes US-Zone 33; Deutscher Wetterdienst: Bad Kissingen, Germany, 1952.

39. Hess, P.; Brezowsky, H. Katalog der Grosswetterlagen Mitteleuropas-2. Neu Bearb. U. Erg. Aufl. Berichte des Dtsch. Wetterdienstes; Deutscher Wetterdienst: Bad Kissingen, Germany, 1969; Volume 15.

40. Hess, P.; Brezowsky, H. Katalog der Grosswetterlagen Europas 1881-1976/3. verbesserte und ergänzte Aufl. Berichte des Dtsch. Wetterdienstes; Deutscher Wetterdienst: Bad Kissingen, Germany, 1977; Volume 15.

41. Werner, P.C.; Gerstengarbe, F.W. Katalog der Grosswetterlagen Europas (1881-2009): Nach Paul Hess und Helmut Brezowsky. Potsdam Institute for Climate Impact Research-PIK Report; Potsdam Institut für Klimafolgenforschung: Potsdam, Germany, 2010.

42. Petrow, T.; Zimmer, J.; Merz, B. Changes in the flood hazard in Germany through changing frequency and persistence of circulation patterns. Nat. Hazards Earth Syst. Sci. 2009, 9, 1409-1423. [CrossRef]

43. CGIAR-CSI. Available online: https://cgiarcsi.community/about/ (accessed on 23 May 2019).

44. SRTM. Available online: http://srtm.csi.cgiar.org/ (accessed on 23 May 2019).

45. Tanrikulu, M. Türkiye'de Toprak Etüt-Haritalama Çalişmalari ve Harvey Oakes (Soil Survey-Mapping Studies in Turkey and Harvey Oakes). Akad. Bakis Derg. 2017, 64, 664-678.

46. EEA-European Environment Agency. CORINE Land Cover-Methodology; EU Publications: Luxembourg City, Luxembourg, 1995; pp. 1-163, ISBN 92-826-2579-6. 
47. Copernicus-Corine Land Cover. Available online: https://land.copernicus.eu/pan-european/corine-landcover (accessed on 31 May 2019).

48. Nied, M.; Hundecha, Y.; Merz, B. Flood-initiating catchment conditions: A spatio-temporal analysis of large-scale soil moisture patterns in the Elbe River basin. Hydrol. Earth Syst. Sci. 2013, 17, 1401-1414. [CrossRef]

49. Brocca, L.; Melone, F.; Moramarco, T.; Morbidelli, R. Antecedent wetness conditions based on ERS scatterometer data. J. Hydrol. 2009, 364, 73-87. [CrossRef]

50. Özer, Z. Su Yapılarının Projelendirilmesinde Hidrolojik ve Hidrolik Esaslar-Teknik Rehber. In Hydrological and Hydraulic Principles in Designing Water Structures-Technical Guide, 1st ed.; Ankara Köy Hizmetleri Genel Müdürlüğü Yayınları: Ankara, Turkey, 1990; p. 714.

51. Masoudian, M.; Theobald, S. Influence of land surface topography on flood hydrograph. J. Am. Sci. 2011, 7, 354-361. [CrossRef]

52. Rama, V.A. Drainage basin analysis for characterization of 3rd order watersheds using Geographic Information System (GIS) and ASTER data. J. Geomat. 2014, 8, 200-210.

53. Candan, O.; Akal, C.; Koralay, E.; Okay, A.I.; Oberhänsli, R.; Prelević, D.; Mertz-Kraus, R. Carboniferous granites on the northern margin of Gondwana, Anatolide-Tauride Block, Turkey-Evidence for southward subduction of Paleotethys. Tectonophys. 2016, 683, 349-366. [CrossRef]

54. Faniran, A. The index of drainage intensity-A provisional new drainage factor. Aust. J. Sci. 1968, 31, 328-330.

55. Horton, R.H. Erosional development of streams and their drainage basins; hydrophysical approach to quantitative morphology. Geol. Soc. Am. Bull. 1945, 56, 275-370. [CrossRef]

56. Prachansri, S. Analysis of Soil and Land Cover Parameters for Flood Hazard Assessment: A Case Study of the Nam Chun Watershed, Phetchabun, Thailand. Master's Thesis, International Institute for Geo-Information Science and Earth Observation, Enschede, The Netherlands, March 2007.

57. Rogger, M.; Agnoletti, M.; Alaoui, A.; Bathurst, J.C.; Bodner, G.; Borga, M.; Chaplot, V.; Gallart, F.; Glatzel, G.; Hall, J.; et al. Land use change impacts on floods at the catchment scale: Challenges and opportunities for future research. Water Resour. Res. 2017, 53, 5209-5219. [CrossRef]

58. Yim, O.; Ramdeen, K.T. Hierarchical Cluster Analysis: Comparison of Three Linkage Measures and Application to Psychological Data. Quant. Methods Psychol. 2015, 11, 8-21. [CrossRef]

59. Behrens, T.; Schmidt, K.; Rossel, R.A.V.; Gries, P.; Scholten, T.; Macmillan, R.A. Spatial modelling with Euclidean distance fields and machine learning. Eur. J. Soil Sci. 2018, 69, 757-770. [CrossRef]

60. Unal, Y.; Kindap, T.; Karaca, M. Redefining the climate zones of Turkey using cluster analysis. Int. J. Clim. 2003, 23, 1045-1055. [CrossRef]

61. Qian, G.; Sural, S.; Gu, Y.; Pramanik, S. Similarity between euclidean and cosine angle distance for nearest neighbor queries. Proc. ACM Symp. Appl. Comput. 2004, 2, 1232-1237. [CrossRef]

62. Mimmack, G.M.; Mason, S.J.; Galpin, J.S. Choice of Distance Matrices in Cluster Analysis: Defining Regions. J. Clim. 2001, 14, 2790-2797. [CrossRef]

63. Milligan, G.W.; Cooper, M.C. Methodology Review: Clustering Methods. Appl. Psychol. Meas. 1987, 11, 329-354. [CrossRef]

64. Şahinalp, M.S. Neden ve sonuçlarıyla Şanlıurfa İlinde yaşanan sel felaketleri, 28-29 Ekim, 01 Kasım 2006 (Flood disasters in Şanlıurfa Province with their causes and consequences, 28-29 October, 1 November 2006). Türk Coğrafya Derg. 2007, 49, 89-122. Available online: https://dergipark.org.tr/tr/pub/tcd/issue/21232/227838 (accessed on 29 May 2020).

65. Kömüscü, A.Ü.; Celik, S.; Ceylan, A. 8-12 Eylül 2009 Tarihlerinde Marmara Bölgesi'nde Meydana Gelen Sel Olayının Yağış Analizi (Rainfall analysis of the flood event that occurred in Marmara Region on 8-12 September 2009). Coğrafi Bilimler Dergisi. 2011, 9, 209-220. [CrossRef]

66. Özdemir, O.; Bozyurt, M.A. Ankara'da Oraj Türleri ve Yıl İçindeki Dağılışları (Thunderstorm Types in Ankara and Their Annual Distribution). Afyon Kocatepe Üniversitesi, Sos. Bilim. Derg. 2003, 1, 116-130. 
67. Ceylan, A.; Alan, I.; Ugurlu, A. Causes and effects of flood hazards in Turkey. Int. Congr. River Basin Manag. 2007, 29, 22-24.

68. NOAA National Centers for Environmental Information. State of the Climate: Global Hazards for March 2004. Available online: https://www.ncdc.noaa.gov/sotc/hazards/200403 (accessed on 12 March 2020).

69. Buldur, A.D.; Pınar, A.; Başaran, A. 5-7 March 2004 Tarihli Göksu Nehri Taşkını ve Silifke'ye Etkisi (Göksu River Flood and Its Effect on Silifke). Selçuk Üniversitesi Sosyal Bilimler Enstitüsü Dergisi 2007, 17, 139-160.

70. Istanbul Metropolitan Municipality, Disaster Coordination Center. Türkiye'de ve Dünya'da meydana gelen afetler, 21-27 Mayis 2007 (Disasters in the world and Turkey, 21-27 May 2007). Afet Bülteni. 2007. Available online: http://www.ibb.gov.tr/sites/akom/documents/afet_bulteni_2007_21.html (accessed on 30 March 2020).

71. Avc1, V.; Sunkar, M. Giresun'da sel ve taşkin oluşumuna neden olan Aksu çayi ve Batlama deresi havzalarinin morfometrik analizleri (Morphometric analysis of Aksu and Batlama stream basins causing flood in Giresun). İstanbul Üniversitesi Coğrafya Dergisi 2015, 30, 91-119.

72. Sahin, K. Carsamba Ovasi ve yakin cevresinde sel felaketi, 27 Mayis 2000 (Flood disaster in the Carsamba Plain and its vicinity, 27 May 2000). Turk Cografya Dergisi 2002, 39, 79-95.

73. Kömüşçü, A.M.; Erkan, A.; Çelik, S. Analysis of Meteorological and Terrain Features Leading to the Izmir Flash Flood, 3-4 November 1995. Nat. Hazards 1998, 18, 1-25. [CrossRef]

74. Yilmaz, F.K. Antalya'nin Günlük Yağiş Özellikleri ve Şiddetli Yağişlarin Doğal Afetler Üzerine Etkisi (Daily Rainfall Characteristics of Antalya and Heavy Rainfall's Influence on Natural Disasters). Sos. Bilim. Derg. 2008, X, 19-65.

75. Hudson, P.; Botzen, W.J.W. Cost-benefit analysis of flood-zoning policies: A review of current practice. Wiley Interdiscip. Rev. Water 2019, 6, 1-21. [CrossRef]

76. Akyar, H. Ankara'yi Su Basti (Flooding in Ankara). 350Ankara. 2018. Available online: https://350ankara. org/ankarayi-su-basti/ (accessed on 11 March 2020).

77. NOAA National Centers for Environmental Information. State of the Climate: Global Hazards for September 2009. Available online: https://www.ncdc.noaa.gov/sotc/hazards/200909 (accessed on 12 March 2020).

78. NOAA National Centers for Environmental Information. State of the Climate: Global Hazards for July 2006. Available online: https://www.ncdc.noaa.gov/sotc/hazards/200607 (accessed on 12 March 2020).

79. Anonymous (4 July 2006). Sel 24 saatte 7 can ald1 (Flooding caused 7 fatalities in 24 hours). Milliyet. Available online: https://www.milliyet.com.tr/pembenar/sel-24-saatte-7-can-aldi-162909 (accessed on 12 March 2020).

80. Anonymous (4 July 2006). Sel, felakete dönüştü 6 ölü, binlerce evsiz (Flood turned into disaster: 6 fatalities, thousands of homeless. Hurriyet. Available online: https://www.hurriyet.com.tr (accessed on 12 March 2020).

81. Anonymous (3 July 2006). Vize'de sel baskını (Flooding in Vize). Vatan. Available online: www.gazetevatan. com/vize-de-de-sel-baskini-81229-gundem/ (accessed on 12 March 2020).

82. Anonymous (4 July 2006). Sel ağıt yaktırdı (Flooding caused lament). Yeni Safak. Available online: https://www.yenisafak.com/gundem/sel-agit-yaktirdi-2699608 (accessed on 12 March 2020).

83. Anonymous (4 July 2006). Seller can alıyor (Flooding caused several fatalities). Sabah. Available online: http://arsiv.sabah.com.tr/2006/07/03/gun98.html (accessed on 12 March 2020).

84. Artan, G. Mersin'de Yasanan Bir Afet: 1968 Sel Baskini (A disaster in Mersin: 1968 Flood Event). Icel Sanat Kulübü Aylik Bülteni. 1997, 58, 32.

85. Yüksek, Ö.; Kankal, M.; Ucuncu, O. Assessment of big floods in the Eastern Black Sea Basin of Turkey. Environ. Monit. Assess. 2012, 185, 797-814. [CrossRef] [PubMed]

86. Sunkar, M.; Denizdurduran, M. Kahramanmaraş'ta Yaşanan Sel ve Taşkın Olaylarının Sebep ve Sonuçları Causes and Effects of Flood and Torrent Events that Occurred in Kahramanmaraş. In Proceedings of the UJES 2015, IV. Ulusal Jeomorfoloji Sempozyumu, Samsun, Turkey, 15-16 October 2015.

87. Bahadir, M. Samsun'da Meydana Gelen 4 Temmuz ve 6 Ağustos 2012 Taşkinlarinin Klimatik Analizi (Climatic Analysis of the Floods on 4 July and 6 August 2012 in Samsun). Coğrafya Derg. 2014, 29, $28-50$.

88. Cellek, M. Bartin ve cevresi sel felaketleri (Flood disasters in Bartin and its vicinity). Bartin74. Available online: http://www.bartin74.net/sayfalar/sel.asp (accessed on 12 March 2020). 
89. Turgut, Ü. Doğu Karadeniz Bölgesinde Sel Felaketine Neden Olan Sinoptik Modellerin Tahmin Tekniği Açısından İncelenmesine Dönük Karşılaştırmalı Bir Araştırma (A Comparative Research on the Investigation of Sinoptic Models Causing Flood Disaster in Eastern Black Sea Region in Terms of Forecasting Technique). TMMOB Dis. Symp. 2007, 387-394. Available online: http://www.imo.org.tr/resimler/ekutuphane/pdf/3896. pdf (accessed on 29 May 2020).

90. Toprak Haritalama Ünitesi Poligon Öznitelik Tablosu_FAO (Soil Mapping Units Attribute Table-FAO). Available online: http://www.fao.org/tempref/NR/GeoSpatial/turkey/soil_zip/Topraklejand.doc (accessed on 1 July 2019).

(C) 2020 by the authors. Licensee MDPI, Basel, Switzerland. This article is an open access article distributed under the terms and conditions of the Creative Commons Attribution (CC BY) license (http://creativecommons.org/licenses/by/4.0/). 